\title{
New and little known net-winged beetles (Coleoptera: Lycidae) from the Crocker Range Mountains, Sabah, East Malaysia
}

\section{Новые и малоизвестные жкуки-краснокрылы (Coleoptera: Lycidae) с горного хребта Крокер, Сабах, Восточная Малайзия}

\author{
Sergey V. Kazantsev \\ С.В. Казанцев
}

Insect Centre, Donetskaya 13-326, Moscow 109651, Russia. E-mail: kazantss@mail.ru Инсект-центр, ул. Донецкая 13-326, Москва 109651, Россия.

KEY WORDS: Coleoptera, Lycidae, new species, Oriental region.

КЛЮЧЕВЫЕ СЛОВА: Coleoptera, Lycidae, новые виды, Ориентальный регион.

ABSTRACT. Fourteen new species of net-winged beetles, Calochromus pardus, Cautires atrantiacus, C. curtelamellatus, C. daimon, C. kurbatovi, Dilophotes banjaranensis, Libnetus muscosus, Metanoeus kompantsevi, Plateros triangulifer, Pyrotes crockerensis, Xylobanellus nigrosanguineus, Xylobanus nigrobrunneis, $X$. peregrinus and $X$. ziminae spp.n., are described from the Crocker Range and Mount Kinabalu (Sabah, Malaysia) from elevation over $1500 \mathrm{~m}$ above sea level. A new name Cautires lycifacies nom.n. is proposed to replace Cautires kinabalensis Dudkova et Bocák, 2010, nec C. kinabalensis Kleine, 1932. The endemic Cautires asperoides Kleine, 1932, C. borneensis Dudkova et Bocák, 2010, C. kinabalensis Kleine, 1932, C. lycifacies nom.n., Libnetus gununganus Kazantsev, 2005, L. maurus Kazantsev, 2005, Metanoeus pendleburyi Kleine, 1932, Xylobanus contrarius Kleine, 1932 and X. longereticulatus Kleine, 1932 are illustrated.

РЕЗЮМЕ. Четырнадцать новых видов жуковкраснокрылов, Calochromus pardus, Cautires atrantiacus, C. curtelamellatus, C. daimon, C. kurbatovi, Dilophotes banjaranensis, Libnetus muscosus, Metanoeus kompantsevi, Plateros triangulifer, Pyrotes crockerensis, Xylobanellus nigrosanguineus, Xylobanus nigrobrunneis, $X$. peregrinus и $X$. ziminae spp.n, описываются с горного хребта Крокер и горы Кинабалу (Сабах, Малайзия) с высот более 1500 м над уровнем моря. Предлагается новое название Cautires lycifacies nom.n. для замещения Cautires kinabalensis Dudkova et Bocák, 2010, nec C. kinabalensis Kleine, 1932. Приводятся иллюстрации эндемичных Cautires asperoides Kleine, 1932, C. bicoloratus Kleine, 1932, C. kinabalensis Kleine, 1932, C. lycifacies nom.n.,
Libnetus gununganus Kazantsev, 2005, L. maurus Kazantsev, 2005, Metanoeus pendleburyi Kleine, 1932, Xylobanus contrarius Kleine, 1932 и X. longereticulatus Kleine, 1932.

\section{Introduction}

First species of net-winged beetles from the island of Borneo, also known as Kalimantan, were described from the lowland tropical rainforest, mostly of Sarawak [Waterhouse, 1878, 1879; Bourgeois, 1883, 1892, 1906; Kleine, 1926a, b, 1927a, b, 1928]. Quite a few of these were also registered in Malay peninsula and/or in Sumatra, or, vice versa, species from those two areas were found in Borneo [Kleine, 1933a, b].

However, when it came to studying material from the montane tropical rainforest, at higher elevation, especially on Mount Kinabalu [Pic, 1912, 1936; Kleine, 1932, 1933a, b], almost all discovered lycid taxa turned out to be local endemics. Further contributions to the knowledge of the Borneo montane rainforest Lycidae were only adding data to prove it [Kazantsev, 1997; 1998, 2003, 2004, 2009, 2014; Malohlava, Bocák, 2009, 2011].

A study of additional material from the Crocker Range Mountains, which Mount Kinabalu is actually part of, from elevation ranging from 1500 to 2700 meters above sea level has led to a discovery of another fourteen new species of this group of beetles. These new species are described below, and additional information, including habitus photographs, is given on some of the poorly known old taxa.

The following acronym is used in this paper: ICM Insect Center, Moscow.

How to cite this article: Kazantsev S.V. 2018. New and little known net-winged beetles (Coleoptera: Lycidae) from the Crocker Range Mountains, Sabah, East Malaysia // Russian Entomol. J. Vol.27. No.3. P.255-270. doi: 10.15298/rusentj.27.3.04 


\section{Material and Methods}

For examination the beetles were relaxed in water, then their detached abdomina were kept for several hours in $10 \% \mathrm{KOH}$ at room temperature. The $\mathrm{KOH}$ treated aedeagi and terminal abdominal segments were then placed in micro vials with glycerin for photographing.

MSP-1 zoom stereoscopic dissecting microscope with $x 8-x 80$ magnification range was used. Photographs were taken with Canon EOS 6D camera and Canon MPE $65 \mathrm{~mm}$ lens.

\section{Taxonomy}

Erotinae Leconte, 1881

Dictyopterini Houlbert, 1922

Type genus: Dictyoptera Latreille, 1829.

Pyrotes Kazantsev, 2004

Type species: Pyropterus sculpturatus C.O. Waterhouse, 1878 (original designation).

\section{Pyrotes crockerensis Kazantsev, sp.n.} Figs 1-3.

MATERIAL. Holotype, $\sigma^{7}$, [E] Malaysia: Sabah prov., Banjaran Crocker Mts, Gunung Alab peak, 1650-1800 m, 30.IV-
27.V.1996, M. Strba \& R. Hergovits leg. (ICM); paratype, ㅇ, E Malaysia: Sabah, Kinabalu Mt., S slopes, $6.01^{\circ} \mathrm{N}, 116.54^{\circ} \mathrm{E}, 1500$ 1700 m, 17-22.I.2018, S. Kazantsev leg. (ICM).

DESCRIPTION. Male. Dark brown to black; posterior pronotal angles and elytra red.

Vertex scarcely punctate, hairy, with inconspicuous roundish impression behind antennal prominence. Eyes small, interocular distance ca. 2.8 times greater than eye diameter. Clypeus concave anteriorly, separated from cranium by suture; labrum small, roundish. Maxillary palps slender, ultimate palpomere elongate, narrowed and glabrous distally. Antennal sockets separated by narrow lamina. Antennae narrow, filiform, attaining to elytral three fourths; antennomeres 2 and 3 subequal in size and length, ca. 1.3 times wider long and combined ca. 1.8 times shorter than antennomere 4; antennomeres 3-11 with short dense decumbent pubescence (Fig. 1).

Pronotum transverse, ca. 1.6 times as wide as long, with noticeably concave before hind angles sides, slightly bisinuate basally and convex anteriorly, with acute posterior and rounded anterior angles; median cell diamond-shaped, broad, directly connected with anterior and not attaining to posterior margin. Scutellum subquadrate, parallel-sided and deeply triangularly emarginate at apex (Fig. 1).

Elytra narrow, long, ca. 3.2 times longer than wide at humeri, with four equally developed primary costae; all interstices with one row of cells; cells mostly moderately transverse, in most cases width not greater than 1.5 times their length; pubescence uniform (covering also bottom of cells),
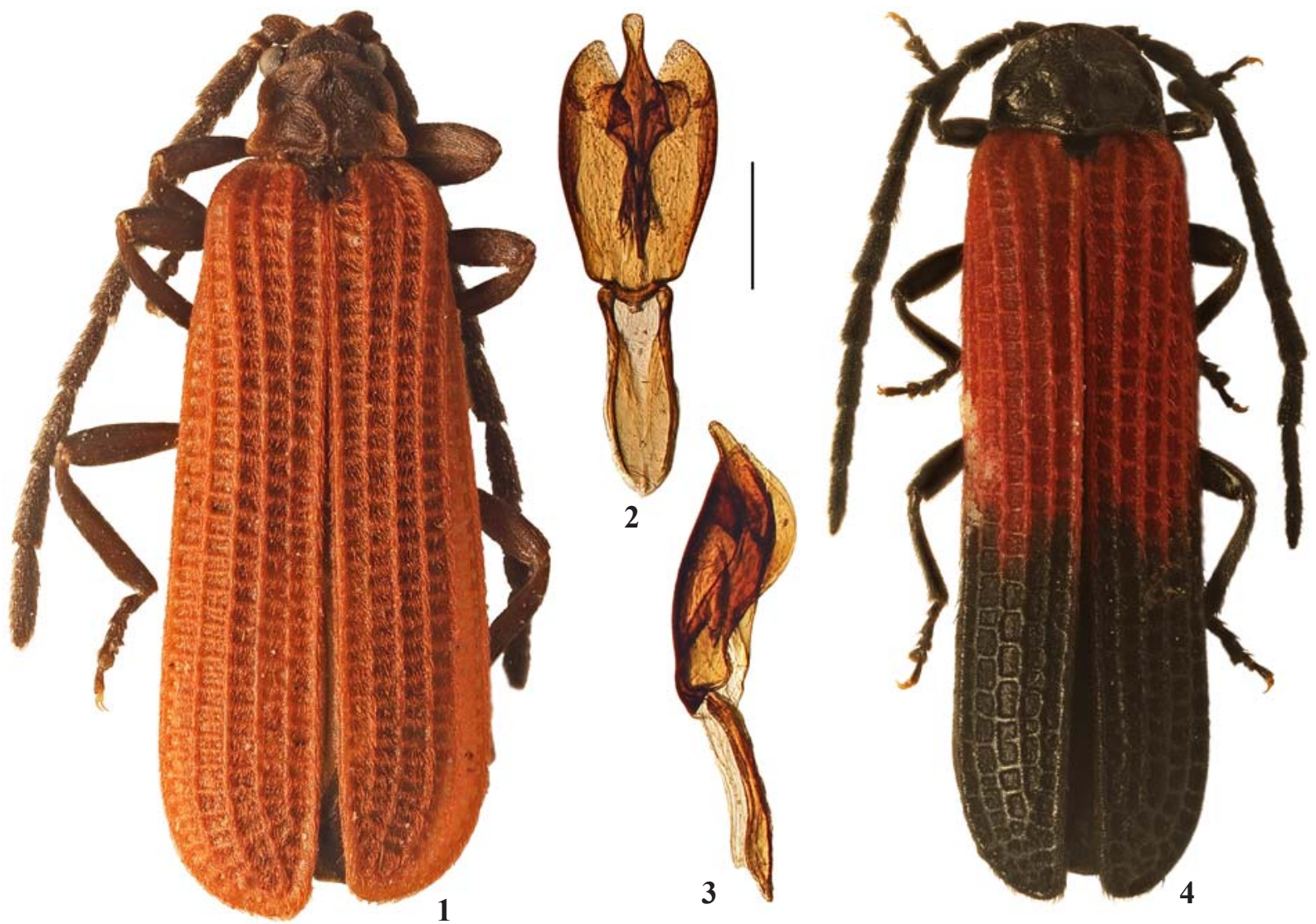

Figs 1-4. General view and aedeagus of Pyrotes and Xylobanellus, holotypes: $1-3-P$. crockerrensis sp.n.; $4-X$. nigrosanguineus sp.n.; 1-3 - male; 4 - female; 1, 4 - general view; 2-3 - aedeagus; 1 , 4 - dorsally; 2 - ventrally; 3 - laterally. Scale: $0.5 \mathrm{~mm}$.

Рис. 1-4. Общий вид и эдеагус Pyrotes и Xylobanellus, голотипы: $1-3-$ P. crockerrensis sp.n.; $4-X$. nigrosanguineus sp.n.; $1-$ 3 - самец; 4 - самка; 1, 4 - общий вид; 2-3 - эдеагус; 1, 4- сверху; 2 - снизу; 3 - сбоку. Масштабная линейка: 0,5 мм. 
dense, short and decumbent. Femoris and tibiae straight, narrow; tarsomeres 1 and 2 narrow, with small apical plantar pad, tarsomeres 3 and 4 inconspicuously widened distally (Fig. 1).

Aedeagus symmetric, with short, constricted before apex, conspicuously widened in the middle in frontal and curved in lateral aspect median lobe; parameres oval, semi-open ventrally, with acute apices; phallobase elongate and narrow, ca. 2.8 times longer than wide and ca. 0.9 length of median lobe, without lateral apodemes and with short median suture proximally (Figs 2-3).

Female. Similar to male, but antennae somewhat shorter.

Length: 7.5-7.8 mm. Width (humerally): $1.9-2.0 \mathrm{~mm}$.

DIAGNOSIS. Pyrotes crockerensis sp.n. is apparently close to Pyrotes sculpturatus (Waterhouse, 1878), known from the lowland rainforest of Sarawak, distinguishable by the dark head and mostly dark pronotum, noticeably less transverse elytral cells (in P. sculpturatus width of the greater part of cells is ca. 3 times their length) and the structure of the aedeagus, with constricted before apex and more curved in lateral aspect median lobe and more narrow phallobase (Figs 2-3).

ETYMOLOGY. The new species is named after the mountain range where the type series was collected.

\section{Conderini Bocák et Bocáková, 1990}

Type genus: Conderis Waterhouse, 1878.

\section{Xylobanellus Kleine, 1930}

Type species: Xylobanellus atricolor Kleine, 1930 (by monotypy).

\section{Xylobanellus nigrosanguineus Kazantsev, sp.n.} Fig. 4.

MATERIAL. Holotype,,+ E Malaysia: Sabah, Crocker Range, Gunung Alab Stn, $5.82^{\circ} \mathrm{N}, 116.34^{\circ} \mathrm{E} 1850-2000 \mathrm{~m}, 23-28 . I .2018$, S. Kazantsev leg. (ICM).

DESCRIPTION. Female. Black; elytra in proximal three fifths blood-red.
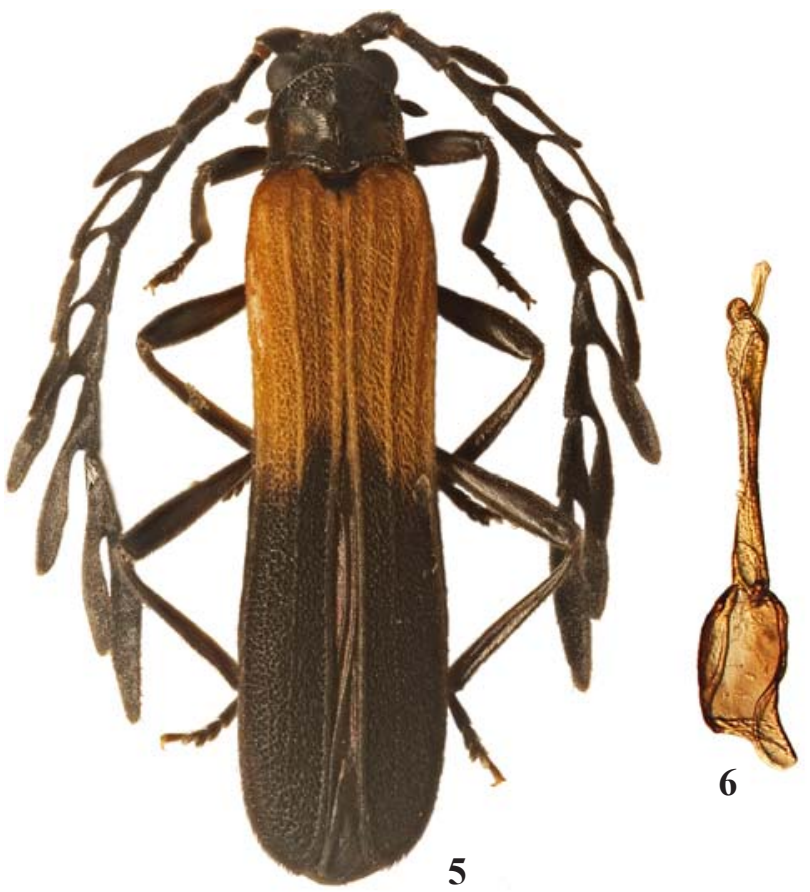

Figs 5-8. General view and aedeagus of Dilophotes banjaranensis sp.n.: 5-7 - holotype male; 4 - paratype female; 5, 8 - general view; 6-7 - aedeagus; 5,8 - dorsally; 6 - ventrally; 7 - laterally. Scale: $0.5 \mathrm{~mm}$.

Рис. 5-8. Общий вид и эдеагус Dilophotes banjaranensis sp.n.: 5-7 — голотип, самец; 4 - паратип, самка; 5, 8 - общий вид; 6-7 - эдеагус; 5, 8 - сверху; 6 - снизу; 7 - сбоку. Масштабная линейка: 0,5 мм.

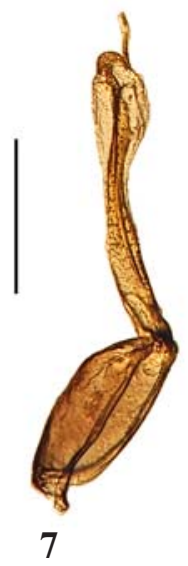

Vertex shining, scarcely punctate, very inconspicuously impressed behind antennal prominence. Eyes small, interocular distance ca. 2.3 times greater than eye diameter. Maxillary palps short, ultimate palpomere triangularly widened, oblique distally. Antennal sockets separated by relatively broad lamina. Antennae filiform, attaining to elytral three fifths; antennomere 3 ca. 3.1 times longer than antennomere 2 and ca. 1.3 times shorter than antennomere 4 ; antennomeres 3-11 with short dense decumbent pubescence (Fig. 4).

Pronotum transverse, ca. 1.6 times as wide as long, with short straight sides, bisinuate basally and rounded anteriorly, with acute posterior and rounded anterior angles; median cell broad, rounded posteriorly and triangular anteriorly, connected with anterior and posterior margins via keels. Scutellum subquadrate, slightly narrowing distally and feebly emarginate at apex (Fig. 4).

Elytra narrow, long, ca. 3.7 times longer than wide at humeri, slightly dehiscent, with four prominent, almost equally developed primary costae; all interstices with one row of cells; cells mostly elongate, in most cases length ca. 1.5 times greater than width; pubescence scarce, relatively long and semi-erect. Femoris and tibiae straight, narrow; tarsomeres 1 and 2 narrow, with apical plantar pad, tarsomeres 3 and 4 inconspicuously widened (Fig. 4).

Male. Unknown.

Length: $6.7 \mathrm{~mm}$. Width (humerally): $1.7 \mathrm{~mm}$.

DIAGNOSIS. Xylobanellus nigrosanguineus sp.n. resembles $X$. postsignatus Kleine, 1932, also from Mount Kinabalu, separable by the relatively longer antennomere 3 (which is ca. 1.5 times shorter than antennomere 4 in $X$. postsignatus) and elongate elytral cells (transverse in $X$. postsignatus) (Fig. 4).

ETYMOLOGY. The name of the new species is derived from the Latin for "black" and "blood-red", according to its coloration.

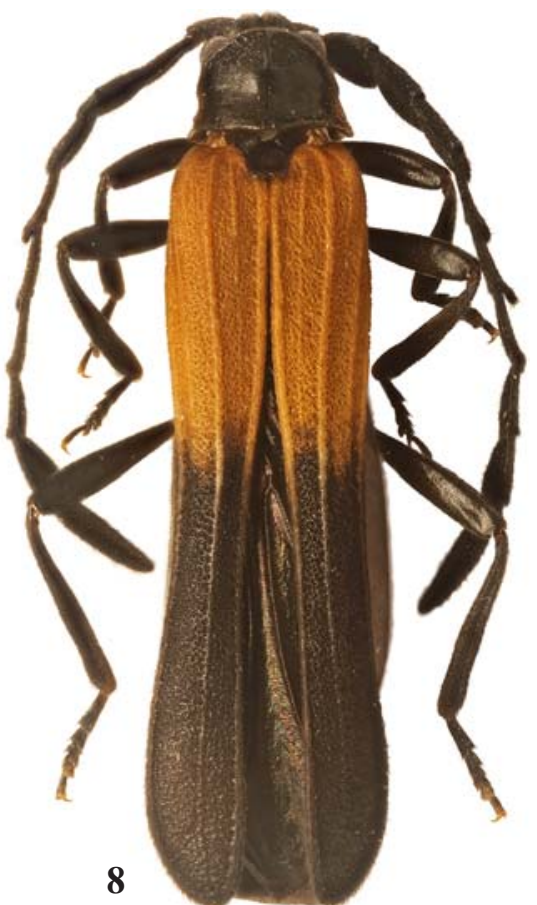


Lycinae Laporte, 1836

Dilophotini Kleine, 1929

Type genus: Dilophotes C.O. Waterhouse, 1879.

Dilophotes C.O. Waterhouse, 1879

Type species: Dilophotes exilis C.O. Waterhouse, 1878 (original designation).

\section{Dilophotes banjaranensis Kazantsev, sp.n.}

Figs 5-8.

MATERIAL. Holotype, $0^{7}$, E Malaysia: Sabah, Crocker Range, Gunung Alab Stn, $5.82^{\circ} \mathrm{N}, 116.34^{\circ} \mathrm{E}, 1850-2000 \mathrm{~m}, 23-28 . \mathrm{I} .2018$, S. Kazantsev leg. (ICM); paratypes, 3 +P , same label (ICM).

DESCRIPTION. Male. Dark brown to black; antennomere 2 light brown, anterior half of elytra ochre testaceous.

Vertex shining, finely punctate, inconspicuously impressed behind antennal prominence, with distinct narrow median groove. Eyes relatively small, interocular distance ca. 1.5 times greater than eye diameter. Maxillary palps slender, relatively long, ultimate palpomere elongate, oval, flattened distally. Antennal sockets separated by narrow lamina. Antennae strongly flattened, serrate, attaining to elytral two thirds; antennomere $3 \mathrm{ca} .8$ times longer than antennomere 2 and ca. 1.2 times shorter than antennomere 4 ; antennomeres 3-11 with short decumbent pubescence (Fig. 5).

Pronotum transverse, ca. 1.4 times as wide as long, with almost parallel sides, slightly concave before posterior angles, bisinuate basally and triangularly produced anteriorly, with narrow acute posterior and broadly rounded anterior angles. Scutellum subquadrate, narrowing distally and emarginate at apex (Fig. 5).

Elytra narrow, long, ca. 3.9 times longer than wide at humeri, parallel-sided, concave in the middle and dehiscent in
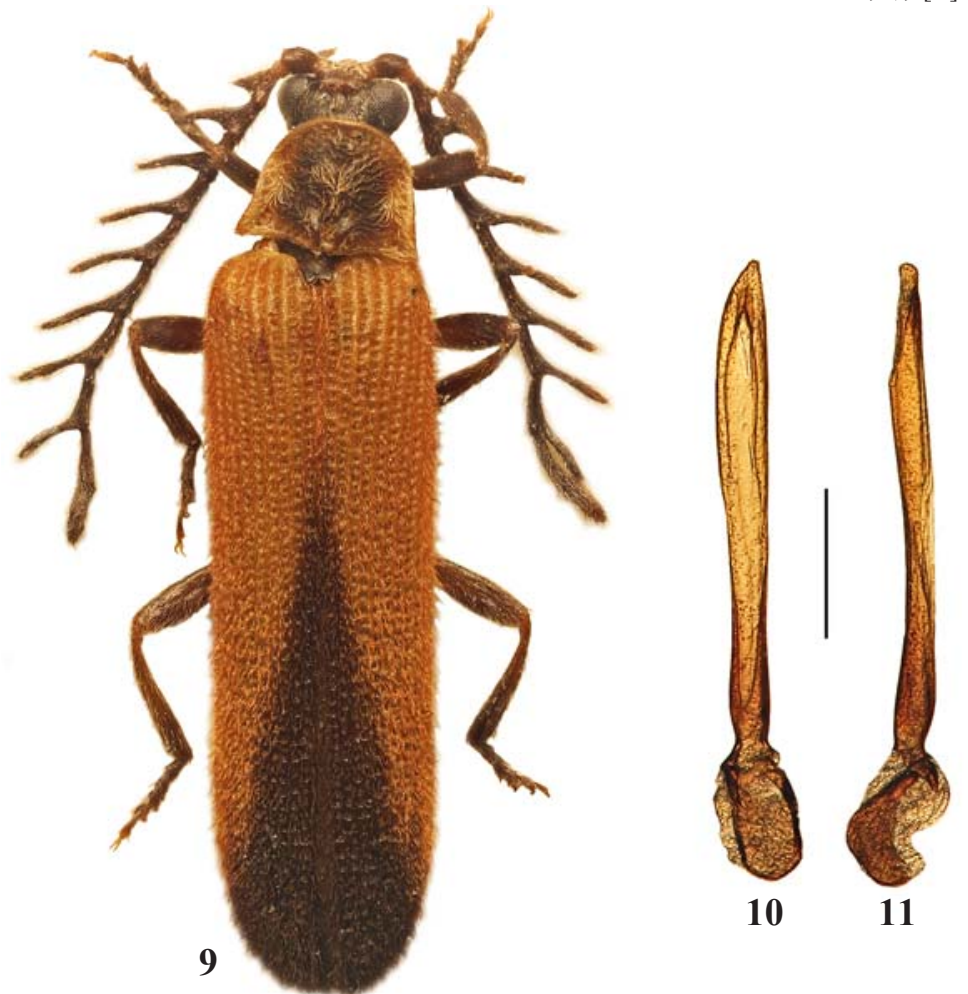

posterior half, with two complete almost equally developed primary costae 2 and 4 and noticeable in proximal third primary costa 1; all interstices finely and densely areolate; pubescence dense, short and decumbent. Femoris and tibiae straight, narrow; tarsomeres 1 and 2 narrow, with small apical plantar pad, tarsomeres 3 and 4 inconspicuously widened distally (Fig. 5).

Aedeagus with narrow, slightly bent in lateral aspect and dilated apically median lobe, provided with small narrow distal process; phallobase prominent, strongly asymmetric, ca. 0.6 length of median lobe (Figs 6-7).

Female. Similar to male, but eyes much smaller, with interocular distance ca. 2.7 times greater than eye diameter, and antennae somewhat shorter and non-flabellate (Fig. 8).

Length: $6.1-7.8 \mathrm{~mm}$. Width (humerally): $1.2-1.7 \mathrm{~mm}$.

DIAGNOSIS. Dilophotes banjaranensis sp.n. is readily distinguishable from other Dilophotes species by the coloration, flabellate antennae and the structure of the aedeagus (Figs 5-7).

ETYMOLOGY. The name of the new species is derived from the Malay "banjaran" for "mountain range", alluding to the Crocker Range where the type series was collected.

\section{Platerotini Kleine, 1929}

Type genus: Plateros Bourgeois, 1879.

\section{Plateros Bourgeois, 1879}

Type species: Eros brasiliensis Lucas, 1857 (subsequsent designation by Zaragoza, 1999).

\section{Plateros triangulifer Kazantsev, sp.n.}

Figs 9-11.

MATERIAL. Holotype, $\sigma^{7}$, [E] Malaysia: Sabah prov., Banjaran Crocker Mts, Gunung Alab peak, 1650-1800 m, 30.IV-27.V. 1996, M. Strba \& R. Hergovits leg. (ICM); paratypes: 2 우, same

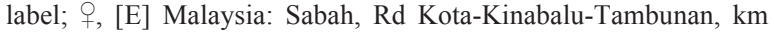

Figs 9-12. General view and aedeagus of Plateros and Libnetus, holotype males: 9-11 — P. triangulifer sp.n.; 12 - L. maurus; 9 , 12 general view; 10-11 - aedeagus; 9, 12 - dorsally; 10 - ventrally; 11 - laterally. Scale: $0.5 \mathrm{~mm}$.

Рис. 9-12. Общий вид и эдеагус Plateros и Libnetus, голотипов, самцов: 9-11 - P. triangulifer sp.n.; 12 - L. maurus; 9, 12 общий вид; 10-11 - эдеагус; 9, 12 - сверху; 10 - снизу; 11 - сбоку. Масштабная линейка: 0,5 мм. 
52, 1600-1800 m, 2-5.VII.2002, S. Kurbatov \& Sv. Zimina leg. (ICM).

DESCRIPTION. Male. Dark brown to black; antennomere 2 and tarsomere 5 distally light brown; pronotal margins and elytra, except in triangularly produced to proximal third along suture patch, orange red.

Vertex shining, scarcely punctate, slightly impressed and bearing median narrow keel behind antennal prominence. Eyes relatively small, interocular distance ca. 1.3 times greater than eye diameter. Maxillary palps slender, ultimate palpomere elongate, parallel-sided, oblique and glabrous distally. Antennal sockets separated by moderately broad lamina. Antennae flabellate, reaching slightly over elytral half; antennal stems nearly cylindrical, flabellae narrow; antennomere $3 \mathrm{ca}$. 3.1 times longer than antennomere 2 and ca. 1.1 times shorter than antennomere 4; antennomere 3 strongly dentate, flabellae of antennomeres 4 and 5 ca. 1.1 and 1.3 times respectively longer than relative stems; antennomeres 3-11 with relatively long suberect pubescence (Fig. 9).

Pronotum transverse, ca. 1.4 times as wide as long, trapezoidal, with almost straight sides, bisinuate basally and semi-circular anteriorly, with acute posterior and rounded anterior angles; densely pubescent. Scutellum subquadrate, nearly parallel-sided, emarginate at apex (Fig. 9).

Elytra narrow, long, ca. 3.3 times longer than wide at humeri, slightly narrowing distally, with four slender, equally developed primary costae, not much different from secondary ones; all interstices double rows of small roundish cells; pubescence dense, semi-erect, relatively long. Femoris and tibiae straight, femoris relatively broad, tibiae narrow; all tarsomeres narrow, tarsomeres 1 and 2 with apical plantar pad, tarsomeres 3 and 4 slightly widened distally (Fig. 9).

Aedeagus with narrow, straight, slightly dilated distally median lobe, somewhat pointed apically in frontal and rounded in lateral view; ventral opening nearly as long as median lobe; phallobase narrow and short, ca. 0.2 length of median lobe (Figs 10-11).

Female. Similar to male, but eyes somewhat smaller, antennae simply dentate.

Length: 4.4-6.1 mm. Width (humerally): $1.0-1.6 \mathrm{~mm}$.

DIAGNOSIS. Plateros triangulifer sp.n. is easily separable from all Plateros species of the region by the coloration pattern and antennal structure, as well as by the structure of the aedeagus (Figs 9-11).

ETYMOLOGY. The name of the new species is derived from the Latin for "bearing a triangle", according to the coloration of its elytra.

VARIATION. In two of the paratypes the pronotum is entirely dark brown to black.

Libnetini Bocák et Bocáková, 1990

Type genus: Libnetus C.O. Waterhouse, 1878.

Libnetus C.O. Waterhouse, 1878

Type species: Libnetus pumilio C.O. Waterhouse, 1878 (original designation)

\section{Libnetus maurus Kazantsev, 2005}

$$
\text { Fig. } 12 .
$$

Libnetus maurus Kazantsev, 2005: 26.

MATERIAL: Holotype, $\sigma^{7}$, «Malaysia: Sabah prov., Banjaran Crocker Mts, Gunung Alab peak, 1650-1800 m, 30.IV-27.V.1996, M. Strba \& R. Hergovits leg.»; «Libnetis maurus sp.n.», «Paratype» (ICM).

DISTRIBUTION. Altitudes over 1,500 $\mathrm{m}$ asl in the Crocker Range Mountains, Sabah, East Malaysia.

\section{Libnetus gununganus Kazantsev, 2005} Figs 13-15.

Libnetus gununganus Kazantsev, 2005: 26.

MATERIAL: Holotype, $\sigma^{7}$, «Malaysia: Sabah prov., Banjaran Crocker Mts, Gunung Alab peak, 1650-1800 m, 30.IV-27.V.1996, M. Strba \& R. Hergovits leg.»; «Libnetis gununganus sp.n.», «Holotype» (ICM).

DISTRIBUTION. Altitudes over $1,500 \mathrm{~m}$ asl in the Crocker Range Mountains, Sabah, East Malaysia.

\section{Libnetus muscosus Kazantsev, sp.n. Figs 16-18}

MATERIAL. Holotype, $\sigma^{\top}$, «N Borneo, Kinabalu, 2700 m, mossy forest, 17-24.VI.1995, S. Kazantsev leg.», «Libnetis gununganus sp.n.», «Paratype» (ICM).

DESCRIPTION. Male. Dark brown to black; elytra ochre testaceous.

Vertex dull, prominently transversely impressed behind antennal prominence. Eyes large, interocular distance ca. 1.4 times shorter than eye diameter. Maxillary palps slender, ultimate palpomere elongate, pointed and glabrous distally. Antennal sockets separated by minute lamina. Antennae oval in cross-section, parallel-sided, attaining to elytral three fourths; antennomere $3 \mathrm{ca}$. 6.9 times longer than antennomere 2 and ca. 1.3 times shorter than antennomere 4; antennomeres 3-11 with short semi-erect pubescence (Fig. 16).

Pronotum transverse, ca. 1.75 times as wide as long, trapezoidal, with straight sides, bisinuate basally and slightly convex anteriorly, with prominent acute posterior and blunt anterior angles. Scutellum subquadrate, somewhat narrowing distally and slightly emarginate at apex (Fig. 16).

Elytra narrow, long, ca. 3.3 times longer than wide at humeri and ca. 9.8 times longer than pronotum, with four slender, complete, almost equally developed primary costae; all interstices finely and densely areolate; pubescence dense, short and decumbent. Femoris and tibiae straight, very narrow; all tarsomeres narrow, tarsomeres 1 and 2 with apical plantar pad, tarsomeres 3 and 4 slightly widened distally (Fig. 16).

Aedeagus symmetric, elongate, straight, moderately broad, with widening in the middle and tapering distally median piece, provided with paired clawed ventral processes and narrow, evenly bent in lateral aspect median spike; parameres free, elongate, oval, divided by distinct suture at proximal opening; phallobase transverse, oval, with conspicuous median suture (Figs 17-18).

Female. Unknown.

Length: $7.7 \mathrm{~mm}$. Width (humerally): $1.7 \mathrm{~mm}$.

DIAGNOSIS. Libnetus muscosus sp.n. is apparently related to L. gununganus Kazantsev, 2004, separable by the noticeably smaller pronotum, longer and distinctly widened distally elytra and certain details of the aedeagus, such as clawed ventral processes, evenly bent in lateral aspect median spike, parameres conspicuously divided by suture at proximal opening, etc. (Figs 16-18). On the other hand, it is easily separable from L. pendleburyi Kleine, 1932, also from Kinabalu and of similar coloration and antennal structure, by the less transverse pronotum, which is only 1.75 times wider than long vs. 2.25 times wider than long in L. pendleburyi.

ETYMOLOGY. The name of the new species is derived from the Latin for "mossy", alluding to the type of the forest where the type specimen was collected.

REMARKS. The Holotype of Libnetus muscosus sp.n. is one of the paratypes of L. gununganus. In addition to the habitus, different from the other members of the type series of the latter, it is also different in the above-mentioned details of the aedeagus (Figs 16-18). 
Metriorrhynchini Kleine, 1926

Type genus: Metriorrhynchus Gemminger et Harold, 1869.

Cautires C.O. Waterhouse, 1879

Type species: Lycus [gen. 22] excellens C.O. Waterhouse, 1878 (original designation).

\section{Cautires asperoides Kleine, 1932}

Fig. 19

Cautires asperoides Kleine, 1932: 151.

MATERIAL. ㅇ, N Borneo, Kinabalu, 1500-1700 m, 1718.VI.1995, S. Kazantsev leg.; $\sigma^{7}$, [E] Malaysia: Sabah prov., Banjaran Crocker Mts, Gunung Alab peak, 1650-1800 m, 30.IV-27.V.1996, M. Strba \& R. Hergovits leg.; + , E Malaysia: Sabah, Kinabalu Mt., S slopes, $6.01^{\circ} \mathrm{N}, 116.54^{\circ} \mathrm{E}, 1500-1700 \mathrm{~m}, 17-22 . I .2018$, S. Kazantsev leg.; , E Malaysia: Sabah, Kinabalu Mt., S slopes, $6.02^{\circ} \mathrm{N}, 116.54^{\circ} \mathrm{E}$ 1750-1800 m, 20.I.2018, S. Kazantsev leg.; + , E Malaysia: Sabah, Crocker Range, Gunung Alab Stn, $5.82^{\circ} \mathrm{N}, 116.34^{\circ} \mathrm{E}, 1850-2000 \mathrm{~m}$, 23-28.I.2018, S. Kazantsev leg. (ICM).

DISTRIBUTION. Altitudes over 1,500 $\mathrm{m}$ asl in the Crocker Range Mountains, including Mount Kinabalu, Sabah, East Malaysia.

REMARKS. Unlike in most other Cautires species, in $C$. asperoides flabellae of antennae stem from bases of antennomeres, not from their apices (Fig. 19).
Cautires borneensis Dudkova et Bocák, 2010 Fig. 20

Cautires borneensis Dudkova et Bocák, 2010: 46, replacement name for C. bicoloratus Kleine, 1932: 151 [HM], not C. bicoloratus (Kleine, 1930): 351.

Cautires bicoloratus Kleine, 1932: 151.

MATERIAL. $10 \sigma^{\top} \sigma^{\top}$ and 13 우, N Borneo, Kinabalu Park HQ, $1550 \mathrm{~m}$, at light, 19-24.VI.1995, S. Kazantsev leg.; N Borneo, Kinabalu, 1500-1700 m, 17-18.VI.1995, S. Kazantsev leg.; [E] Malaysia: Sabah prov., Banjaran Crocker Mts, Gunung Alab peak, 1650-1800 m, 30.IV-27.V.1996, M. Strba \& R. Hergovits leg.; [E] Malaysia: Sabah, Kinabalu N.P., $1550 \mathrm{~m}$, at light, 22.VIII.1999, C.F. Lee leg.; Borneo: Sabah, Kinabalu Mt. area, 12 km [E] Kundasang, $1500 \mathrm{~m}, 06^{\circ} 00.703^{\prime} \mathrm{N}, 116^{\circ} 32.060^{\prime} \mathrm{E}, 22-25 . \mathrm{IV} .2012$, A. Kompantsev leg.; Borneo: Sabah, Kinabalu, $1660 \mathrm{~m}, 6.025^{\circ} \mathrm{N}$, $116.59^{\circ}$ E, 18.II.2014, N. Vikhrev leg.; E Malaysia: Sabah, Kinabalu Mt., S slopes, $6.01^{\circ} \mathrm{N}, 116.54^{\circ} \mathrm{E}, 1500-1700 \mathrm{~m}, 17-22 . \mathrm{I} .2018$, S. Kazantsev leg. (ICM).

DISTRIBUTION. Altitudes over $1,500 \mathrm{~m}$ asl in the Crocker Range Mountains, including Mount Kinabalu, Sabah, East Malaysia.

REMARKS. Just like in C. asperoides, in C. borneensis flabellae of antennae stem from bases of antennomeres, not from their apices (Fig. 20).

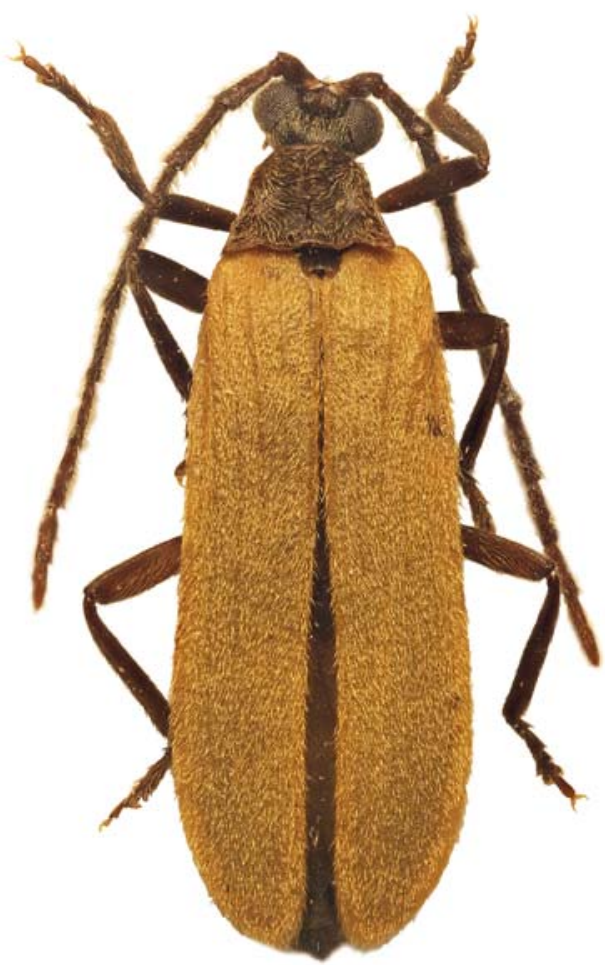

13
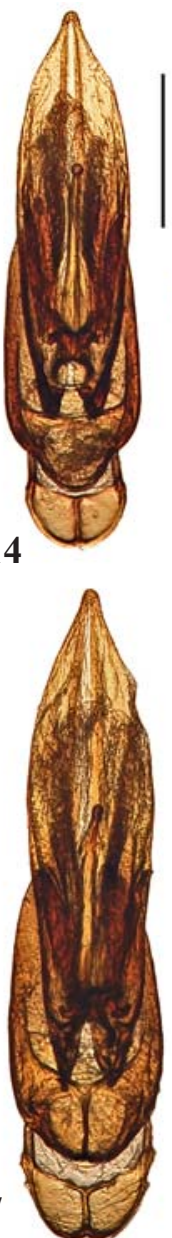
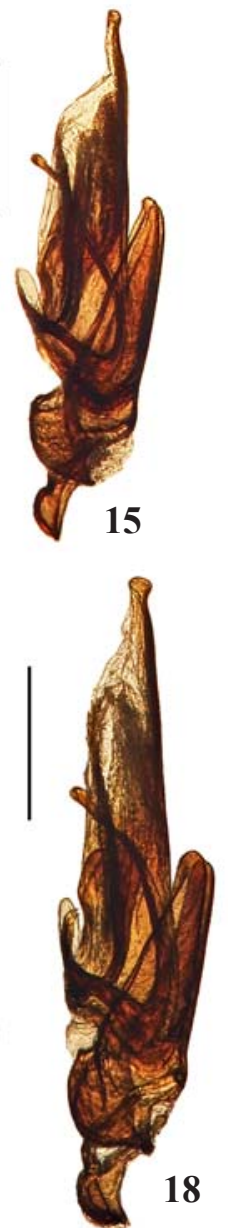

8

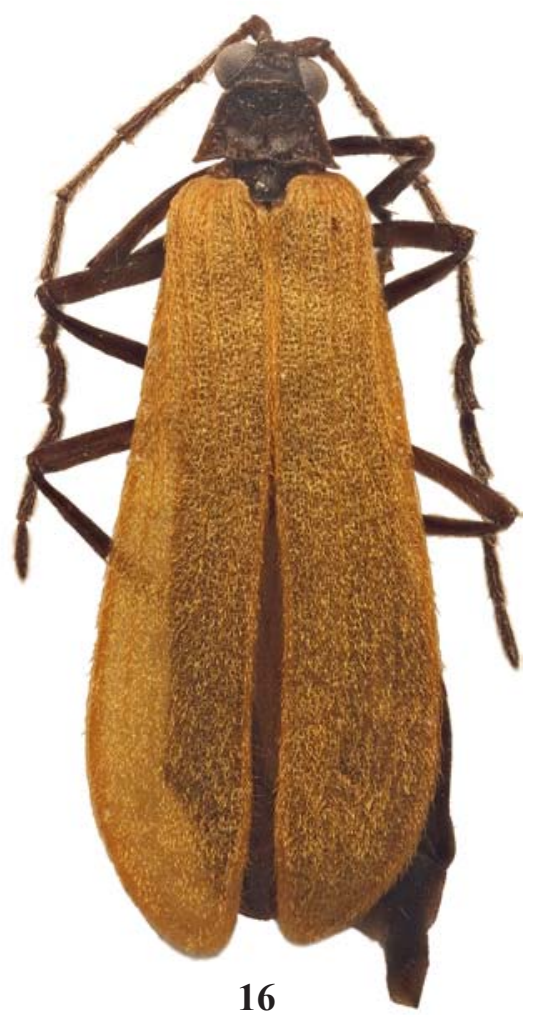

Figs 13-18. General view and aedeagus of Libnetus, holotype males: 13-15 - L. gununganus; 16-18 - L. muscosus sp.n.; 13, 16 general view; 14-15, 17-18 - aedeagus; 13, 16 - dorsally; 14, 17 - ventrally; 15, 18 - laterally. Scales: $0.5 \mathrm{~mm}$.

Рис. 13-18. Общий вид и эдеагус Libnetus, голотипов, самцов: 13-15 - L. gununganus; 16-18 - L. muscosus sp.n.; 13, 16 - общий вид; 14-15, 17-18 - эдеагус; 13, 16 - сверху; 14, 17 - снизу; 15,18 - сбоку. Масштабные линейки: 0,5 мм. 


\section{Cautires kinabalensis Kleine, 1932}

Fig. 21.

Cautires kinabalensis Kleine, 1932: 150.

MATERIAL. $12 \sigma^{7} \sigma^{7}$ and 4 오, N Borneo, Kinabalu, 15001700 m, 22.VI.1995, S. Kazantsev leg.; [E] Malaysia: Sabah prov. Banjaran Crocker Mts, Gunung Alab peak, 1650-1800 m, 30.IV27.V.1996, M. Strba \& R. Hergovits leg.; [E] Malaysia: Sabah, Rd Kota-Kinabalu-Tambunan, km 52, 1700-1800 m, 3-8.VII.2002, S Kurbatov \& Sv. Zimina leg.; Borneo: Sabah, Kinabalu Mt. area, 12 $\mathrm{km}$ [E] Kundasang, $1500 \mathrm{~m}, 0^{\circ} 00.703^{\prime}$ N, 116 32.060' E, 22 25.IV.2012, A. Kompantsev leg.; E Malaysia: Sabah, Crocker Range, Gunung Alab Stn, $5.82^{\circ} \mathrm{N}, 116.34^{\circ} \mathrm{E} 1850-2000 \mathrm{~m}, 23-28 . I .2018$, S. Kazantsev leg. (ICM)

DISTRIBUTION. Crocker Range Mountains, including Mount Kinabalu, Sabah, East Malaysia.

\section{Cautires lycifacies Kazantsev, nom.n.} Fig. 22.

Cautires kinabalensis Dudkova et Bocák, 2010: 44, junior secondary homonym of $C$. kinabalensis Kleine, 1932: 150

Cautires kinabalensis Dudkova et Bocák, 2010: 44, replacement name for $C$. lyciformis (Kleine, 1932): $154[\mathrm{HN}]$, not $C$. lyciformis Pic, 1922: 7

Bulenides lyciformis Kleine, 1932: 154.

MATERIAL. $\sigma^{7}$, [E] Malaysia: Sabah prov., Banjaran Crocker Mts, Gunung Alab peak, 1650-1800 m, 30.IV-27.V.1996, M. Strba \& R. Hergovits leg.; + , same label; $\sigma^{7},[E]$ Malaysia: Sabah, Rd Kota-Kinabalu-Tambunan, km 52, 1700-1800 m, 3-8.VII.2002, S Kurbatov \& Sv. Zimina leg.; $\sigma^{\top}$, E Malaysia: Sabah, Kinabalu Mt. $\mathrm{S}$ slopes, $6.01^{\circ} \mathrm{N}, 116.54^{\circ} \mathrm{E}, 1500-1700 \mathrm{~m}, 17-22 . \mathrm{I} .2018$, S. Kazantsev leg. (ICM).

ETYMOLOGY. The new name is derived from the genus name "Lycus" and the Latin for "appearance", alluding to the shape of its elytra.

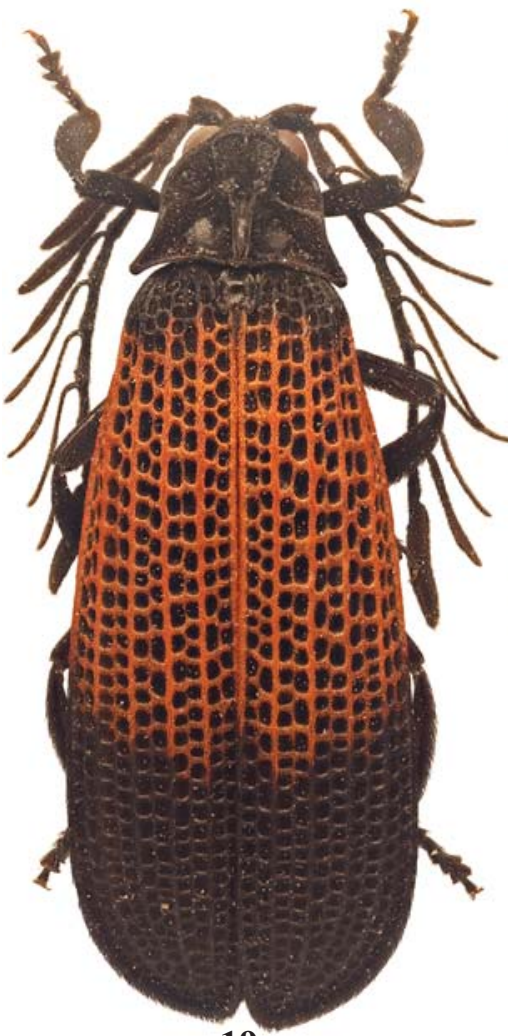

19

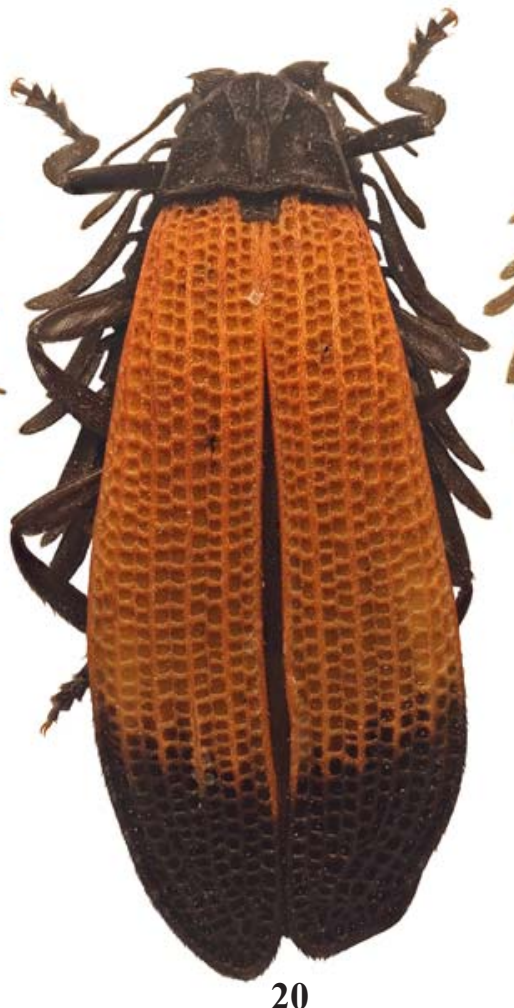

20
DISTRIBUTION. Crocker Range Mountains, including Mount Kinabalu, Sabah, East Malaysia.

\section{Cautires atrantiacus Kazantsev, sp.n.}

Figs 23, 29-30.

MATERIAL. Holotype, O’, N Borneo, Kinabalu Park HQ, 1550 m, at light, 19-24.VI.1995, S. Kazantsev leg. (ICM); paratypes: $\sigma^{7}$, same label; $\sigma^{7}$ and + , [E] Malaysia: Sabah prov., Banjaran Crocker Mts, Gunung Alab peak, 1650-1800 m, 30.IV-27.V.1996, M. Strba \& R. Hergovits leg. (ICM).

DESCRIPTION. Male. Dark brown to black; elytra, except at distal fifth, red orange (Fig. 23).

Vertex shining, finely and densely punctate, with prominent transverse impression behind antennal prominence. Eyes moderately large, interocular distance ca. 1.2 times greater than eye diameter. Maxillary palps slender, ultimate palpomere elongate, narrow, almost parallel-sided, obliquely rounded at apex. Antennal sockets separated by minute lamina. Antennae flabellate, attaining to elytral middle; antennomere 3 ca. 4.1 times longer than antennomere 2 and ca. 1.1 times longer than antennomere 4; flabellae of antennomeres 3 and 4 ca. 1.3 and 1.9 times respectively longer than relative stems; antennomeres 3-11 with short decumbent pubescence (Fig. 23).

Pronotum only slightly transverse, only ca. 1.15 times as wide as long, trapezoidal, with concave sides, conspicuously bisinuate basally and triangularly produced anteriorly, with prominent acute posterior and conspicuous blunt anterior angles; median areole narrow oval, all carinae well developed. Scutellum subquadrate, somewhat narrowing distally and emarginate at apex (Fig. 23).

Elytra, long, ca. 3.7 times longer than wide at humeri, conspicuously widened posteriorly, with four equally devel-

Figs 19-21. General view of Cautires, males: $19-$ C. asperoides; $20-$ - C. borneensis; $21-$ C. kinabalensis.

Рис. 19-21. Общий вид Cautires, самцов: $19-$ - . asperoides; $20-$ C. borneensis; 21 - C. kinabalensis. 
oped primary costae; all interstices with double rows of regular small subquadrate cells; pubescence short and decumbent; bottom of cells hairless (Fig. 23). Femoris and tibiae straight, broad; tarsomeres $2-4$ strongly widened, with prominent plantar pad.

Aedeagus with narrow, slightly bent in lateral aspect and somewhat dilated before apex median lobe, provided with paired small inner sac dents, with short distal hook; phallobase small, ca. 0.2 length of median lobe (Figs 29-30).

Female. Similar to male, but eyes somewhat smaller, antennae only strongly dentate.

Length: $10.7-11.7 \mathrm{~mm}$. Width (humerally): $2.3-2.4 \mathrm{~mm}$.

DIAGNOSIS. Cautires atrantiacus sp.n. is readily distinguishable from the other Cautires species of the area by its coloration, with uniformly red orange proximal part of the elytra, whereas in the other species the elytra are proximally black (e.g., Fig. 23). It may be distinguished from the similar- ly coloured $C$. curtelamellatus sp.n. and C. kurbatovi sp.n. by the elongate and narrowed anteriorly pronotum and the structure of the aedeagus (Figs 29-30).

ETYMOLOGY. The name of the new species is derived from the Latin "ater" for "black" and "aurantiacus" for "orange", alluding to its elytral coloration.

\section{Cautires curtelamellatus Kazantsev, sp.n.}

Figs 24, 31-32.

MATERIAL. Holotype, ơ , E Malaysia: Sabah, Crocker Range, Gunung Alab Stn, $5.82^{\circ} \mathrm{N}, 116.34^{\circ} \mathrm{E}, 1850-2000 \mathrm{~m}, 23-28 . I .2018$, S. Kazantsev leg. (ICM); paratypes, $O^{7}$, N Borneo, Kinabalu, 15001700 m, 17-18.VI.1995, S. Kazantsev leg.; ㅇ, N Borneo, Kinabalu, 1500-1700 m, 22.VI.1995, S. Kazantsev leg.; $ᄋ$, [E] Malaysia: Sabah, Rd Kota-Kinabalu-Tambunan, km 52, 1700-1800 m, 38.VII.2002, S. Kurbatov \& Sv. Zimina leg. (ICM).

DESCRIPTION. Male. Dark brown to black; scutellum testaceous; elytra, except at apices, red orange.

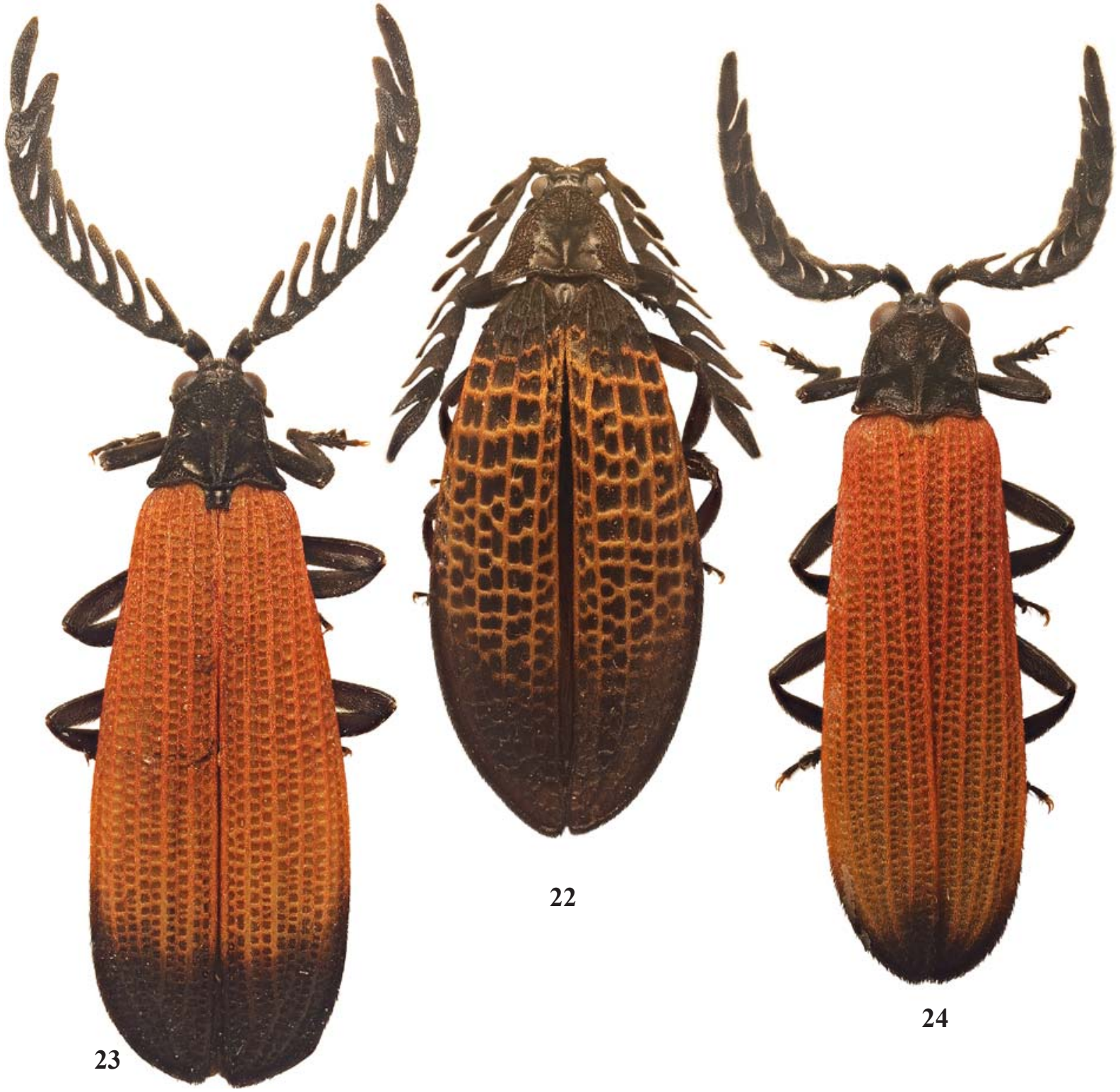

Figs 22-24. General view of Cautires, males: $22-$ C. lycifacies, nom.n.; $23-$ C. atrantiacus sp.n.; $24-$ C. curtelamellatus sp.n.; $23-24$ - holotypes.

Рис. 22-24. Общий вид Cautires, самцов: $22-$ C. lycifacies, nom.n.; 23 - C. atrantiacus sp.n.; $24-$ C. curtelamellatus sp.n.; 2324 - голотипы. 
Vertex shining, finely and densely punctate, prominently transversely impressed behind antennal prominence. Eyes relatively large, interocular distance ca. 1.1 times greater than eye diameter. Maxillary palps slender, ultimate palpomere elongate, narrow, parallel-sided, oblique and glabrous at apex. Antennal sockets separated by short narrow lamina. Antennae flabellate, attaining nearly to elytral middle; antennomere 3 ca. 5 times longer than antennomere 2 and ca. 1.1 times longer than antennomere 4; flabellum of antennomere 3 ca. 1.3 times respectively shorter than relative stem, flabellum of antennomere $4 \mathrm{ca} .1 .1$ times respectively shorter than relative stem; antennomeres 3-11 with short decumbent pubescence (Fig. 24).

Pronotum transverse, ca. 1.2 times as wide as long, trapezoidal, with almost straight sides, bisinuate basally and triangularly produced anteriorly, with truncate median third, anterior angles blunt and conspicuous, posterior small and acute; median areole narrow angular, all carinae well developed. Scutellum subquadrate, slightly widening distally and triangularly emarginate at apex (Fig. 24).

Elytra long, ca. 3.7 times longer than wide at humeri, slightly widened posteriorly, with four equally developed primary costae; all interstices with double rows of regular small subquadrate cells; pubescence short and decumbent; bottom of cells hairless. Femoris and tibiae straight, relatively broad; tarsomeres 2-4 widened, with prominent plantar pad (Fig. 24)

Aedeagus with narrow proximally, slightly curved before apex in lateral aspect and conspicuously dilated distally median lobe, provided with paired small inner sac dents, with short membranous distal 'hook'; phallobase small, ca. 0.2 length of median lobe (Figs 31-32).

Female. Similar to male, but eyes somewhat smaller, antennal lamellae broad and relatively short.

Length: $9.0-13.8 \mathrm{~mm}$. Width (humerally): $2.0-3.5 \mathrm{~mm}$.

DIAGNOSIS. Cautires curtelamellatus sp.n. may be separated from the somewhat similar $C$. atrantiacus sp.n. and C. kurbatovi sp.n. by the testaceous scutellum, slightly transverse pronotum with non-produced laterally posterior angles, relatively short antennal flabellae and the structure of the aedeagus, with conspicuously widened distally median lobe (Figs 24, 31-32).

ETYMOLOGY. The name of the new species is derived from the Latin for "with short lamellae", alluding to its antennal structure.

\section{Cautires daimon Kazantsev, sp.n.}

Figs 25, 33-34.

MATERIAL. Holotype, O, N Borneo, Kinabalu Park HQ, 1550 m, at light, 19-24.VI.1995, S. Kazantsev leg. (ICM); paratypes: +, N Borneo, Kinabalu, 1500-1700 m, 17-18.VI.1995, S. Kazantsev leg.; $3 \mathrm{O}^{7} \mathrm{O}^{7}$ and 5 우, [E] Malaysia: Sabah prov., Banjaran Crocker Mts, Gunung Alab peak, 1650-1800 m, 30.IV-27.V.1996, M. Strba \& R. Hergovits leg.; 2 오, [E] Malaysia: Sabah, Rd Kota-KinabaluTambunan, km 52, 1700-1800 m, 3-8.VII.2002, S. Kurbatov \& Sv. Zimina leg.; + , Borneo: Sabah, Kinabalu Mt. area, $12 \mathrm{~km}[\mathrm{E}]$ Kundasang, $1500 \mathrm{~m}, 06^{\circ} 00.703^{\prime} \mathrm{N}, 116^{\circ} 32.060^{\prime} \mathrm{E}, 22-25 . \mathrm{IV} .2012$, A. Kompantsev leg.; $\bigcirc^{7}+$, Borneo: Sabah, Kinabalu, $1660 \mathrm{~m}, 6.025^{\circ} \mathrm{N}$, $116.59^{\circ} \mathrm{E}, 18 . \mathrm{II} .2014$, N. Vikhrev leg. (ICM).

DESCRIPTION. Male. Dark brown to black; elytra, except at distal fourth, red orange, with smooth transition to black.

Vertex shining, finely punctate, flat behind antennal prominence. Eyes relatively small, interocular distance subequal in length to eye diameter. Maxillary palps slender, ultimate palpomere elongate, nearly parallel-sided, flattened, narrowed and glabrous distally. Antennal sockets separated by triangu- lar lamina. Antennae flabellate, attaining to elytral middle, flabellae stemming from bases of antennomeres; antennomere $3 \mathrm{ca} .8 .8$ times longer than antennomere 2 and ca. 1.3 times longer than antennomere 4; flabellae of antennomeres 3 and 4 ca. 1.8 and 2.8 times respectively longer than relative stems; antennomeres 3-11 with short decumbent pubescence (Fig. 25).

Pronotum transverse, ca. 1.2 times as wide as long, with concave sides, bisinuate basally and triangularly produced anteriorly, with conspicuously produced laterally acute posterior and conspicuous blunt anterior angles; median areole narrow angular, all carinae well developed. Scutellum elongate, almost parallel-sided, emarginate at apex (Fig. 25).

Elytra long, ca. 3.6 times longer than wide at humeri, noticeably widened posteriorly, widest in distal third, with four equally developed primary costae; all interstices with double rows of regular small subquadrate cells; pubescence short and decumbent; bottom of cells hairless. Femoris and tibiae straight, relatively broad; tarsomeres 2-4 widened, tarsomere 1 with plantar pad on ca. two thirds of its length (Fig. 25).

Aedeagus with narrow proximally, straight in lateral aspect and dilated distally median lobe, with long semimembranous distal 'hook'; paired inner sac dents located near middle; phallobase small, about 0.2 length of median lobe (Figs 33-34).

Female. Similar to male, but larger, eyes smaller, antennomeres 3-10 with broad, but shorter lamellae.

Length: $11.6-17.8 \mathrm{~mm}$. Width (humerally): $2.6-4.5 \mathrm{~mm}$.

DIAGNOSIS. Cautires daimon sp.n., being similar in general appearance and antennal structure to C. borneensis, is separable by the uniformly red orange basally elytra, with less conspicuous border between red orange and black apically, and less transverse pronotum with noticeably concave sides and angularly rhomboidal anteriorly median cell, as well as by the distinctly broader distally median lobe of the aedeagus (Figs 25, 33-34).

ETYMOLOGY. The name of the new species is derived from the Greek for "ancestor guardian", as the local indigenous people call Mount Kinabalu, where most of the type specimens were collected, akina-balu, resting place of the ancestral spirits.

\section{Cautires kurbatovi Kazantsev, sp.n.} Figs 26-28.

MATERIAL. Holotype, $\sigma^{7}$, [E] Malaysia: Sabah, Rd KotaKinabalu-Tambunan, km 52, 1700-1800 m, 3-8.VII.2002, S. Kurbatov \& Sv. Zimina leg. (ICM); paratype, $0^{3}$, same label (ICM)

DESCRIPTION. Male. Dark brown to black; elytra, except at apices, red orange.

Vertex shining, finely punctate, transversely impressed behind antennal prominence. Eyes small, interocular distance ca. 1.4 times greater than eye diameter. Maxillary palps slender, ultimate palpomere slightly longer than wide, oblique, flattened and glabrous distally. Antennal sockets separated by triangular lamina. Antennae flabellate, attaining nearly to elytral middle; antennomere $3 \mathrm{ca} .7$ times longer than antennomere 2 and ca. 1.1 times longer than antennomere 4; flabellae of antennomeres 3 and 4 ca. 1.4 and 1.9 times respectively longer than relative stems; antennomeres 3-11 with short decumbent pubescence (Fig. 26).

Pronotum transverse, ca. 1.6 times as wide as long, with noticeably concave sides, bisinuate basally and inconspicuously triangularly produced forward anteriorly, with prominent acute posterior and distinct blunt anterior angles; median areole narrow and short, attaining only to pronotal half, all 
carinae, except lateral ones, well developed. Scutellum elongate, narrowing distally and emarginate at apex (Fig. 26).

Elytra long, ca. 3.6 times longer than wide at humeri, slightly widened posteriorly, with four equally developed primary costae; all interstices with double rows of small subquadrate cells, becoming smaller and rounder in anterior third; pubescence short and decumbent; bottom of cells hairless (Fig. 26). Femoris and tibiae straight, relatively narrow; tarsomeres 2-4 widened, tarsomere 1 with plantar pad on ca. half its length.

Aedeagus with narrow proximally, slightly bent distally in lateral aspect and almost not dilated distally in frontal aspect median lobe, with long, starting nearly from the middle, distal opening; phallobase small, about 0.2 length of median lobe (Figs 27-28).

Female. Unknown.

Length: 8.6-10.8 mm. Width (humerally): $1.9-2.4 \mathrm{~mm}$.

DIAGNOSIS. Cautires kurbatovi sp.n. may be distinguished from the similarly coloured $C$. atrantiacus sp.n. and C. curtelamellatus sp.n. by the conspicuously transverse pronotum with produced laterally posterior angles and small cells in the elytral interstices, especially in their anterior third (Fig. 26), as well as by the structure of the aedeagus, with long distal opening, starting nearly from the middle of the median lobe (Figs 27-28).

ETYMOLOGY. The new species is named after Dr. Sergey Kurbatov (Moscow), the collector of the type series.

\section{Metanoeus C.O. Waterhouse, 1879}

Type species: Lycus [gen. 37] dispar C.O. Waterhouse, 1878 (original designation).

\section{Metanoeus pendleburyi Kleine, 1932}

Fig. 35.

Metanoeus pendleburyi Kleine, 1932: 156.

MATERIAL. $0^{7}$ and 7 우, [E] Malaysia: Sabah prov., Banjaran Crocker Mts, Gunung Alab peak, 1650-1800 m, 30.IV-27.V.1996, M. Strba \& R. Hergovits leg.; [E] Malaysia: Sabah, Kinabalu N.P., $1550 \mathrm{~m}$, at light, 22.VIII.1999, C.-F. Lee leg.; [E] Malaysia: Sabah, Rd Kota-Kinabalu-Tambunan, km 52, 1700-1800 m, 3-8.VII.2002, S. Kurbatov \& Sv. Zimina leg.; E Malaysia: Sabah, Kinabalu Mt., S slopes, $6.01^{\circ} \mathrm{N}, 116.54^{\circ} \mathrm{E}, 1500-1700 \mathrm{~m}, 17-22 . I .2018$, S. Kazantsev leg. (ICM).

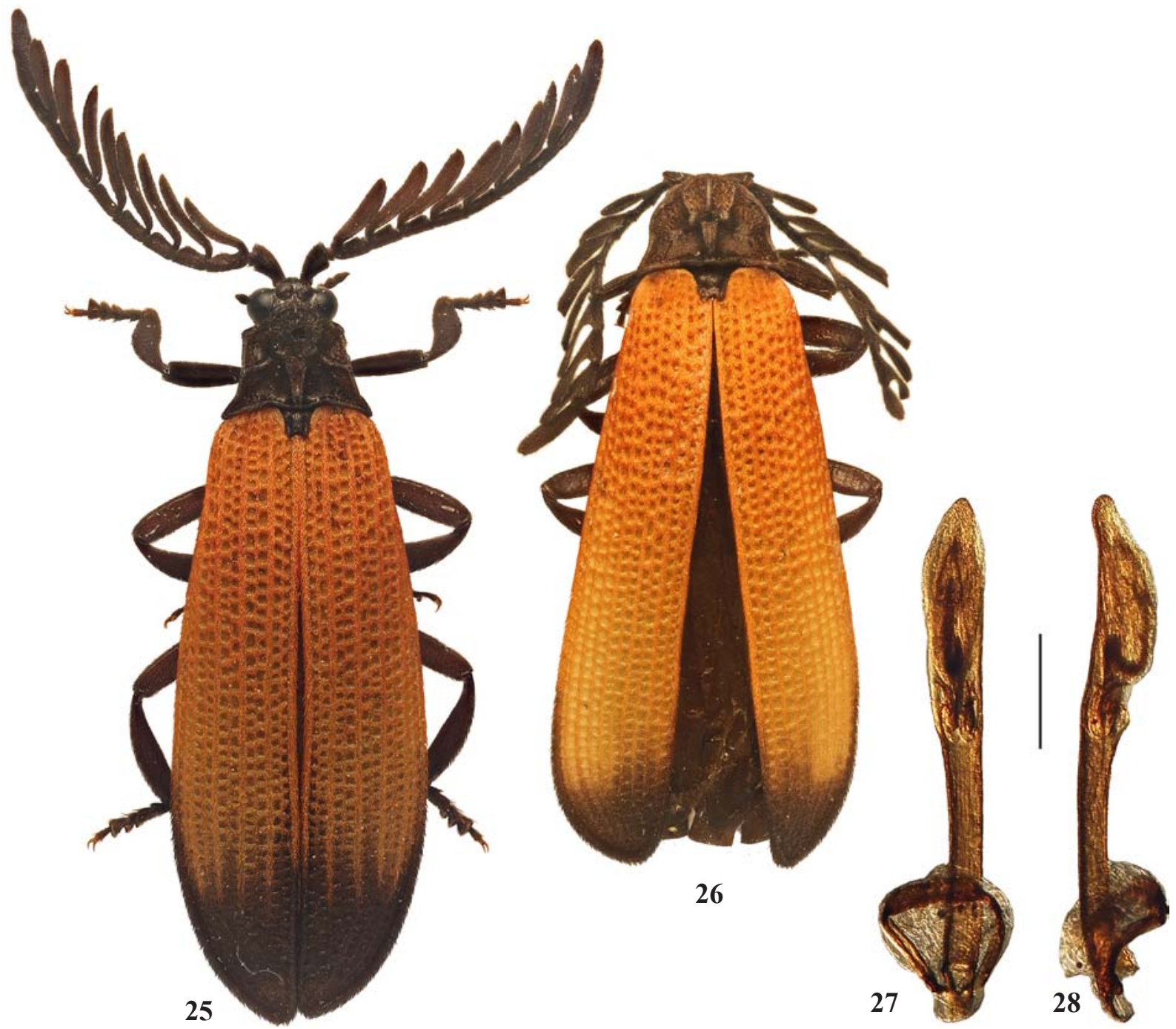

Figs 25-28. General view and aedeagus of Cautires, holotype males: $25-$ C. daimon sp.n.; 26-28 - C. kurbatovi sp.n.; 25-26 general view; 27-28 - aedeagus; 25-26 - dorsally; 27 - ventrally; 28 - laterally. Scale: $0.5 \mathrm{~mm}$.

Рис. 25-28. Общий вид и эдеагус Cautires, голотипов, самцов: 25 - C. daimon sp.n.; 26-28 - C. kurbatovi sp.n.; 25-26 - общий вид; 27-28 - эдеагус; 25-26 - сверху; 27 - снизу; 28 - сбоку. Масштабная линейка: 0,5 мм. 
DISTRIBUTION. Crocker Range Mountains, including Mount Kinabalu, Sabah, East Malaysia.

\section{Metanoeus kompantsevi Kazantsev, sp.n.} Figs 36-38.

MATERIAL. Holotype, $\sigma^{7}$, [E] Malaysia: Sabah prov., Banjaran Crocker Mts, Gunung Alab peak, 1650-1800 m, 30.IV27.V.1996, M. Strba \& R. Hergovits leg. (ICM); paratypes: $0^{7}$, same label; $\sigma^{7}$, Borneo: Sabah, Kinabalu Mt. area, 12 km [E] Kundasang, $1500 \mathrm{~m}, 06^{\circ} 00.703^{\prime} \mathrm{N}, 116^{\circ} 32.060^{\prime}$ E, 22-25.IV.2012, A. Kompantsev leg. (ICM).

DESCRIPTION. Male. Dark brown to black; elytra, except in distal fifth, ochre testaceous.

Vertex shining, finely punctate, broadly shallowly impressed behind antennal prominence. Eyes large, interocular distance ca. 1.2 times shorter than eye diameter. Maxillary palps slender, ultimate palpomere slightly longer than wide, parallel-sided, flattened and glabrous distally. Antennal sockets separated by short narrow lamina. Antennae flabellate, long, attaining to elytral four fifths; flabellae stemming from bases of antennomeres; antennomere $3 \mathrm{ca}$. 10 times longer than antennomere 2 and subequal in length to antennomere 4 ; flabellae of antennomeres 3 and 4 ca. 1.3 and 1.9 times respectively longer than relative stems; antennomeres 3-11 with short decumbent pubescence (Fig. 36).

Pronotum transverse, ca. 1.4 times as wide as long, with straight, almost parallel sides, bisinuate basally and convex anteriorly, with laterally produced acute posterior and conspicuous blunt anterior angles; median areole triangular, moderately broad, all carinae considerably smoothed. Scutellum subquadrate, broadly and deeply emarginate at apex (Fig. 36).

Elytra narrow, long, ca. 4 times longer than wide at humeri, slightly widened posteriorly, with four equally de- veloped primary costae; all interstices with double rows of regular small elongate cells; pubescence dense, short and decumbent; bottom of cells hairless. Femoris and tibiae straight, narrow; tarsomeres 2-4 slightly widened, tarsomere 1 with small apical plantar pad (Fig. 36).

Aedeagus with robust, parallel-sided and rounded apically in frontal aspect and slightly bent in lateral aspect median lobe, with three pairs of sharpened inner sac dents and elongate, relatively broad and constricted apically median spike; phallobase short, about 0.2 length of median lobe, with elongate membranous sac (Figs 37-38).

Female. Unknown.

Length: $10.3-10.4 \mathrm{~mm}$. Width (humerally): $2.1-2.2 \mathrm{~mm}$.

DIAGNOSIS. Metanoeus kompantsevi sp.n. is readily distinguishable from $M$. pendleburyi by the coloration pattern and the structure of the aedeagus (Figs 36-38).

ETYMOLOGY. The new species is named after Dr. Aleksandr Kompantsev (Moscow), one of the collectors of the type series.

\section{Xylobanus C.O. Waterhouse, 1879} tion).

Type species: Lycus costifer Walker, 1858 (original designa-

\section{Xylobanus contrarius Kleine, 1932}

Fig. 39.

Xylobanus contrarius Kleine, 1932: 154

MATERIAL. $6 O^{7} O^{7}$ and 6 OP, [E] Malaysia: Sabah prov., Banjaran Crocker Mts, Gunung Alab peak, 1650-1800 m, 30.IV27.V.1996, M. Strba \& R. Hergovits leg.; [E] Malaysia: Sabah, Rd Kota-Kinabalu-Tambunan, km 52, 1700-1800 m, 3-8.VII.2002, S. Kurbatov \& Sv. Zimina leg. (ICM).

DISTRIBUTION. Crocker Range Mountains, including Mount Kinabalu, Sabah, East Malaysia.

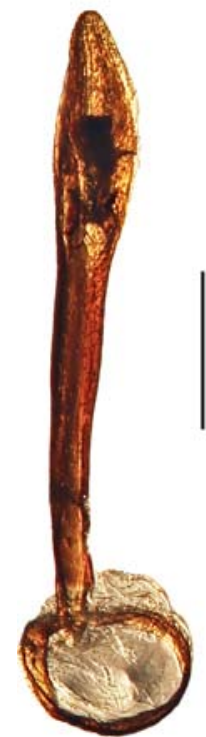

29
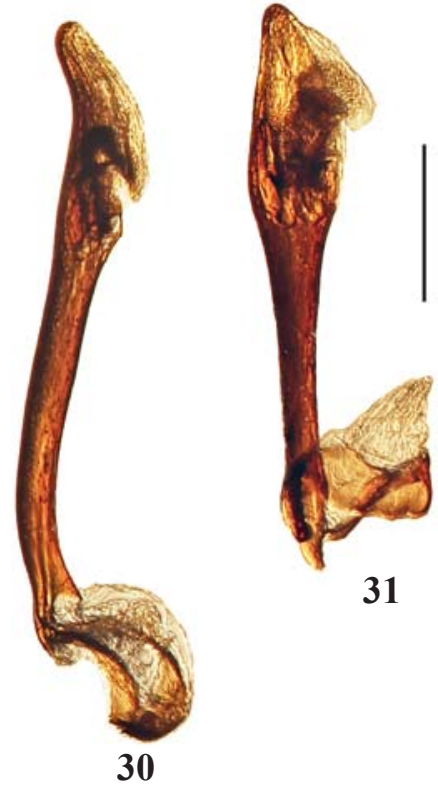

31

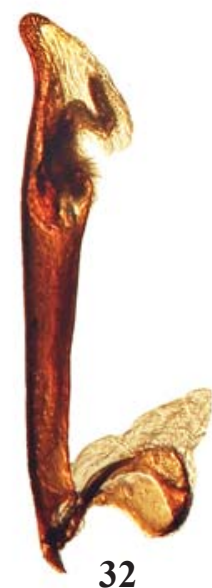

32

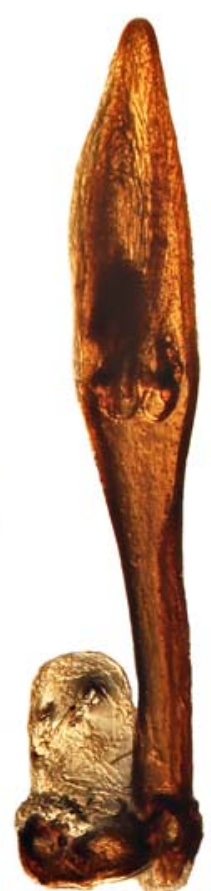

33

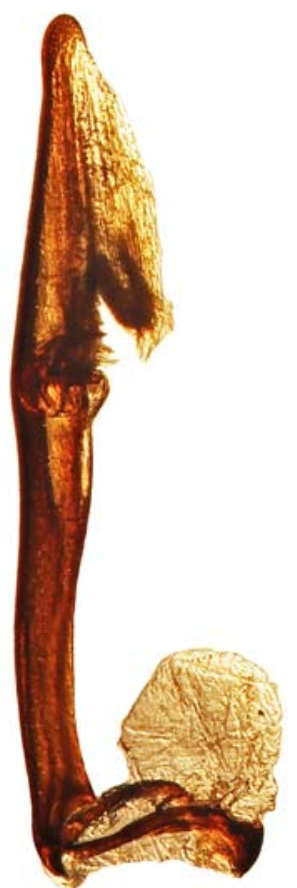

34

Figs 29-34. Aedeagi of Cautires, holotype males: 29-30 - C. atrantiacus sp.n.; 31-32 - C. curtelamellatus sp.n.; 33-34 - C. daimon sp.n.; 29, 31, 33 - ventrally; 30, 32, 34 - laterally. Scales: $0.5 \mathrm{~mm}$.

Рис. 29-34. Эдеагусы Cautires, голотипов, самцов: 29-30-C. atrantiacus sp.n.; 31-32 - C. curtelamellatus sp.n.; 33-34 - C. daimon sp.n.; 29, 31, 33 - снизу; 30, 32, 34 - сбоку. Масштабные линейки: 0,5 мм. 
Xylobanus longereticulatus Kleine, 1932 Fig. 40.

Xylobanus longereticulatus Kleine, 1932: 152.

MATERIAL. $24 \sigma^{7} \sigma^{7}$ and 4 우, N Borneo, Kinabalu, 15001700 m, 17-22.VI.1995, S. Kazantsev leg.; [E] Malaysia: Sabah prov., Banjaran Crocker Mts, Gunung Alab peak, 1650-1800 m, 30.IV-27.V.1996, M. Strba \& R. Hergovits leg.; [E] Malaysia: Sabah, Mt. Kinabalu, 1600-1700 m, 16-30.VII.2002, S. Kurbatov \& Sv. Zimina leg.; Borneo: Sabah, Kinabalu Mt. area, $12 \mathrm{~km}$ [E] Kundasang, $1500 \mathrm{~m}, 06^{\circ} 00.703^{\prime} \mathrm{N}, 116^{\circ} 32.060^{\prime} \mathrm{E}, 22-25 . \mathrm{IV} .2012$, A. Kompantsev leg. (ICM).

DISTRIBUTION. Crocker Range Mountains, including Mount Kinabalu, Sabah, East Malaysia.

\section{Xylobanus nigrobrunneis Kazantsev, sp.n.}

Figs 42, 45-46.

MATERIAL. Holotype, $O^{7}$, [E] Malaysia: Sabah prov., Banjaran Crocker Mts, Gunung Alab peak, 1650-1800 m, 30.IV27.V.1996, M. Strba \& R. Hergovits leg. (ICM); paratype, + , same label (ICM).

DESCRIPTION. Male. Dar brown to black; antennomere 2 light brown; elytral proximal third ochre testaceous, bottom of cell in proximal third also ochre testaceous.

Vertex shining, finely punctate, transversely impressed just behind antennal prominence, convex posteriorly. Eyes relatively small, interocular distance ca. 1.2 times greater

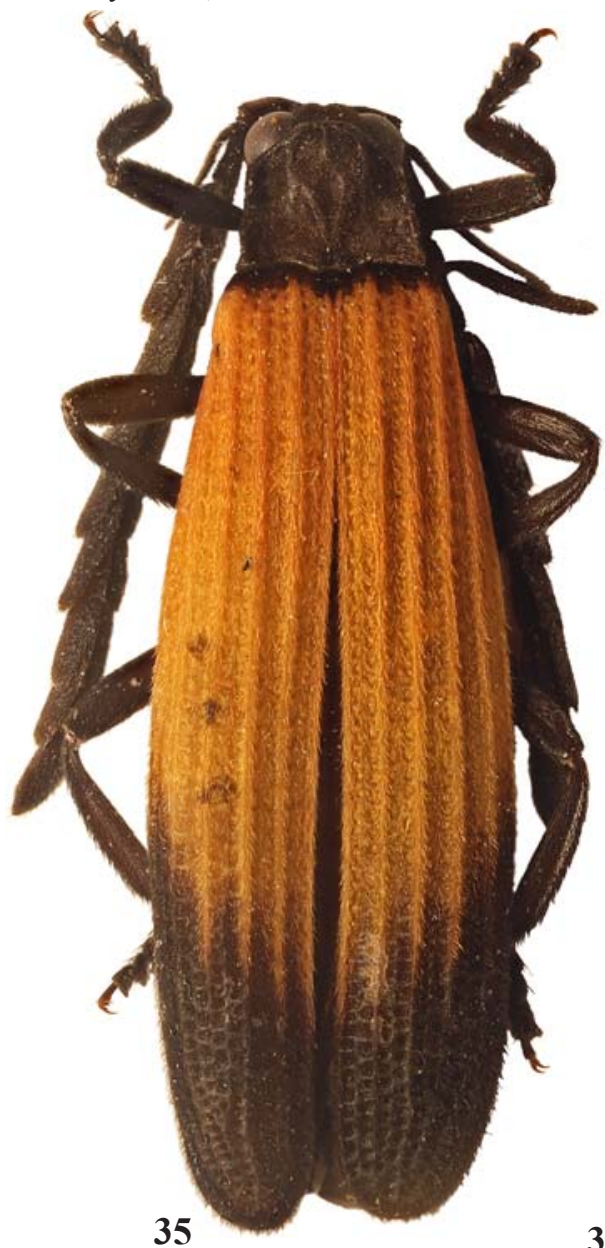

37 than eye diameter. Maxillary palps slender, ultimate palpomere elongate, narrow, parallel-sided flattened and glabrous distally. Antennal sockets separated by minute lamina. Antennae flattened, serrate, attaining to elytral two thirds; antennomere 3 ca. 4.7 times longer than antennomere 2 and ca. 1.1 times shorter than antennomere 4 ; antennomeres 3-11 with short decumbent pubescence (Fig. 42).

Pronotum almost quadrate, only ca. 1.1 times wider than long, with almost parallel, slightly concave sides, bisinuate basally and almost straight anteriorly, with acute posterior and noticeable blunt anterior angles; median areole relatively broad, angular, attaining to 0.7 pronotal length, all carinae straight, well developed. Scutellum transverse, parallel-sided, strongly emarginate at apex (Fig. 42).

Elytra narrow, long, ca. 3.8 times longer than wide at humeri, parallel-sided, with four equally developed primary costae; all interstices with a single row of regular small subquadrate cells; pubescence scarce, short and decumbent. Femoris and tibiae straight, narrow; tarsomeres 3 and 4 slightly widened, tarsomeres 1 and 2 with small apical plantar pad (Fig. 42).

Aedeagus with narrow proximally, slightly bent in lateral aspect and relatively broad distally before apex in frontal aspect median lobe, its apex subquadrate in frontal and rounded in lateral aspect; phallobase about 0.3 length of

Figs 35-38. General view and aedeagus of Metanoeus, males: 35-M. pendleberryi; 36-38 - M. kompantsevi sp.n.; 36-38 - holotype; 35-36 - general view; 37-38 - aedeagus; 35-36 - dorsally; 37 - ventrally; 38 - laterally. Scale: $0.5 \mathrm{~mm}$.

Рис. 35-38. Общий вид и эдеагус Metanoeus, самцов: 35 - M. pendleberryi; 36-38 - M. kompantsevi sp.n.; 36-38 - голотип; 35-36 - общий вид; 37-38 - эдеагус; 35-36 - сверху; 37 - снизу; 38 - сбоку. Масштабная линейка: 0,5 мм. 

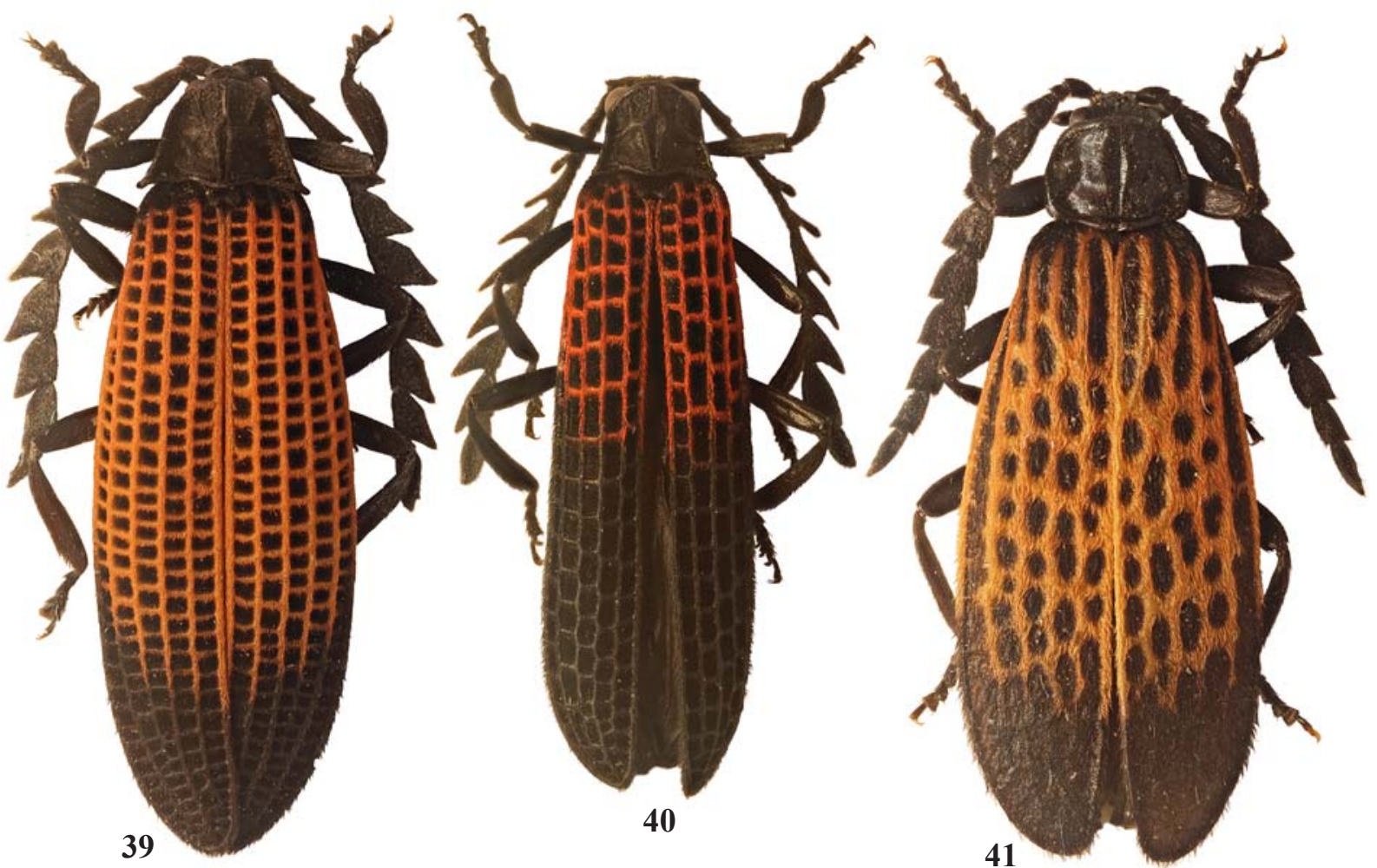

Figs 39-41. General view of Xylobanus and Calochromus: $39-X$. contrarius; $40-X$. longereticulatus; 41 - C. pardus sp.n.; $41-$ holotype; 39-40 - males; 41 - female.

Рис. 39-41. Общий вид Xуlobanus и Calochromus: $39-$ X. contrarius; $40-X$. longereticulatus; 41 - C. pardus sp.n.; 41 — голотип; 39-40 - самцы; 41 - самка.

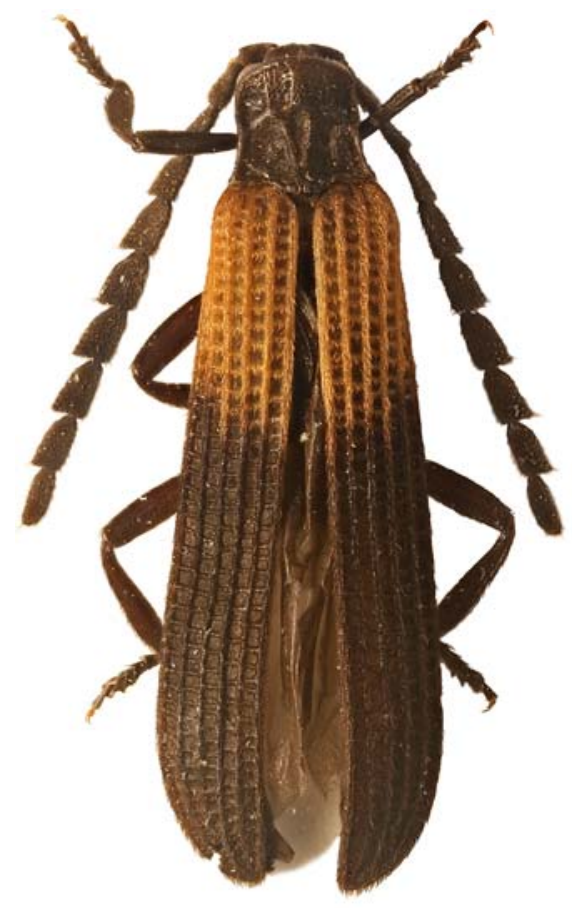

42
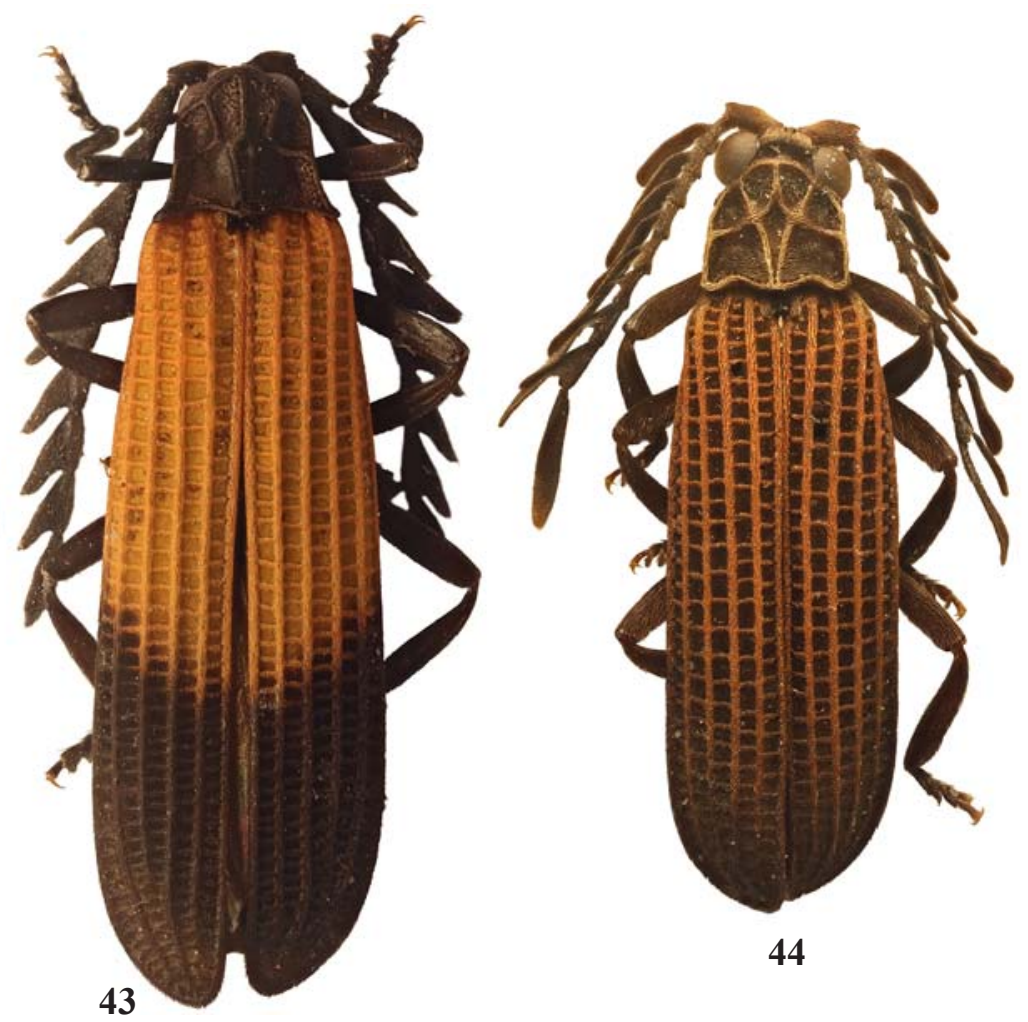

44

Figs 42-44. General view of Xylobanus, holotype males: $42-X$. nigrobrunneis sp.n.; $43-X$. pereginus sp.n.; $44-X$. ziminae sp.n. Рис. 42-44. Общий вид Xylobanus, голотипов, самцов: $42-X$. nigrobrunneis sp.n.; $43-X$. pereginus sp.n.; $44-X$. ziminae sp.n. 
median lobe, its membranous sac over twice as long as median lobe (Figs 45-46).

Female. Similar to male, but larger, eyes smaller, antennae shorter.

Length (male): $6.4 \mathrm{~mm}$. Width (male, humerally): 1.3 $\mathrm{mm}$.

Length (female): $9.5 \mathrm{~mm}$. Width (female, humerally): 1.9 $\mathrm{mm}$

DIAGNOSIS. Xylobanus nigrobrunneis sp.n. is separable from other Xylobanus species of the region by the uniformly ochre testaceous proximal elytral third, with subquadrate cells in the elytral interstices, as well as by the narrow proximally and relatively broad distally before apex median lobe of the aedeagus (Figs 42, 45-56).

ETYMOLOGY. The name of the new species is derived from the Latin for "black" or "brown", according to its elytral coloration.

\section{Xylobanus peregrinus Kazantsev, sp.n.} Figs 43, 47-48.

MATERIAL. Holotype, $\sigma^{7}$, [E] Malaysia: Sabah prov., Banjaran Crocker Mts, Gunung Alab peak, 1650-1800 m, 30.IV27.V.1996, M. Strba \& R. Hergovits leg. (ICM); paratypes: ㅇ, same label; O', N Borneo, Kinabalu, 1500-1700 m, 17-18.VI.1995, S. Kazantsev leg. (ICM).

DESCRIPTION. Male. Dark brown to black; elytra in proximal two thirds orange testaceous, bottom of cells in proximal two thirds also orange testaceous.

Vertex shining, finely punctate, prominently impressed behind antennal prominence. Eyes moderately large, interocular distance ca. 1.2 times greater than eye diameter. Maxillary palps slender, ultimate palpomere elongate, parallel-sided, narrow, flattened and glabrous distally. Antennal sockets separated by short narrow lamina. Antennae flattened, semiflabellate, almost attaining to elytral two thirds; antennomere 3 ca. 5.6 times longer than antennomere 2 and ca. 1.1 times shorter than antennomere 4; flabellae short and broad; antennomeres 3-11 with short decumbent pubescence (Fig. 43).
Pronotum subquadrate, only ca. 1.1 times wider than long, with straight sides, bisinuate basally and noticeably produced forward anteriorly, with prominent narrowly acute posterior and blunt anterior angles; median areole relatively narrow, triangular anteriorly, attaining to 0.6 pronotal length, all carinae well developed, lateral and antero-lateral carinae somewhat curved. Scutellum subquadrate, parallel-sided, triangularly emarginate at apex (Fig. 43).

Elytra long, ca. 3.8 times longer than wide at humeri, very slightly widened posteriorly, with four equally developed primary costae; all interstices with a single row of regular rectangular cells; cells mostly moderately transverse, in most cases width not greater than 1.5 times their length; pubescence dense, short and decumbent; bottom of cells hairless. Femoris and tibiae straight, moderately broad; tarsomeres 2 4 widened, tarsomere 1 with plantar pad on ca. apical fourth (Fig. 43).

Aedeagus relatively robust, with slightly bent in lateral aspect and somewhat widened distally in frontal aspect median lobe, with sclerotised distal hook; phallobase about 0.3 length of median lobe (Figs 47-48).

Female. Similar to male, but larger, eyes smaller, antennae shorter and less dentate.

Length (male): 10.9-11.0 mm. Width (male, humerally): $2.4-2.5 \mathrm{~mm}$.

Length (female): $15.9 \mathrm{~mm}$. Width (female, humerally): $3.8 \mathrm{~mm}$.

DIAGNOSIS. Xylobanus peregrinus sp.n. is separable from the habitually similar X. pendleburyi Kleine, 1932, known only from one female type specimen from Kinabalu, by the complete transverse pronotal carinae and absence of black spots on elytral shoulders (Fig. 43). Also, X. peregrinus sp.n. stands out among other members of the genus due to its aedeagal structure, with sclerotized distal hook (Figs 47-48).

ETYMOLOGY. The name of the new species is derived from the Latin for "stranger" or "alien", according to the peculiar structure of its aedeagus.

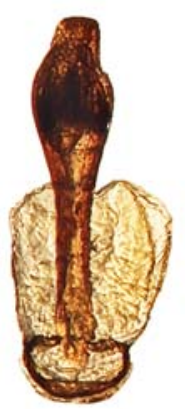

45

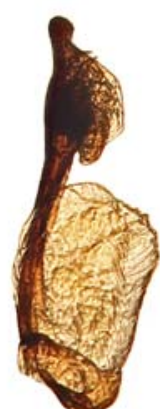

46

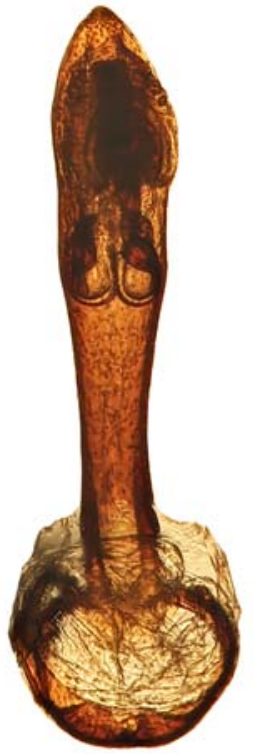

47

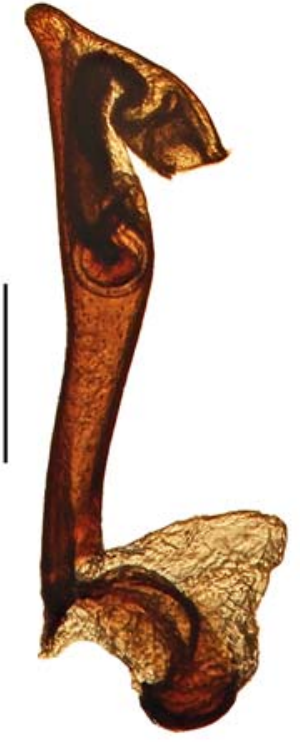

48

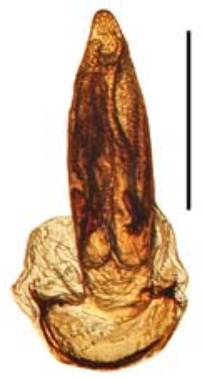

49

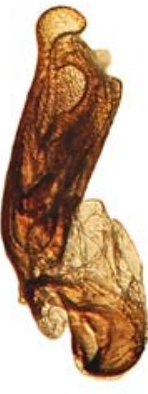

50

Figs 45-50. Aedeagi of Xylobanus, holotype males: 45-46-X. nigrobrunneis sp.n.; 47-48 - X. pereginus sp.n.; 49-50-X. ziminae sp.n.; 45, 47, 49 - ventrally; 46, 48, 50 - laterally. Scales: $0.5 \mathrm{~mm}$.

Рис. 45-50. Эдеагусы Xylobanus, голотипов, самцов: 45-46 - X. nigrobrunneis sp.n.; 47-48 - X. pereginus sp.n.; 49-50 - X. ziminae sp.n.; 45, 47, 49 - снизу; 46, 48, 50 - сбоку. Масштабные линейки: 0,5 мм. 


\section{Xylobanus ziminae Kazantsev, sp.n.} Figs 44, 49-50.

MATERIAL. Holotype, ণ̛, [E] Malaysia: Sabah, Rd KotaKinabalu-Tambunan, km 52, 1600-1800 m, 2-5.VII.2002, S. Kurbatov \& Sv. Zimina leg. (ICM).

DESCRIPTION. Male. Dark brown to black; pronotal costae and margins grayish light brown; elytral costae and transverse ribs, except in distal tenth, reddish brown, with gradual transition border between reddish brown and black parts; bottom of elytral cells dark brown to black.

Vertex shining, finely punctate, prominently impressed behind antennal prominence. Eyes large, interocular distance ca. 1.1 times shorter than eye diameter. Maxillary palps slender, ultimate palpomere elongate, narrow, narrowing and glabrous distally. Antennal sockets separated by triangular lamina. Antennae flabellate, attaining to elytral three fifths; antennomere 3 ca. 10 times longer than antennomere 2 and ca. 1.4 times longer than antennomere 4; antennal stems almost cylindrical, flabellae of antennomeres 3 and 4 ca. 2.3 and 3.7 times respectively longer than relative stems; antennomeres 3-11 with short decumbent pubescence (Fig. 44).

Pronotum subquadrate, only ca. 1.1 times wider than long, with almost parallel straight sides, bisinuate basally and strongly triangularly produced forward anteriorly, with truncate medially anterior fourth, inconspicuously produced posteriorly posterior and rounded anterior angles; median areole relatively large, with concave anteriorly sides, attaining to 0.8 pronotal length, all carinae well developed. Scutellum subquadrate, parallel-sided, emarginate at apex (Fig. 44).

Elytra moderately long, ca. 3.3 times longer than wide at humeri, parallel-sided, with four equally developed primary costae; all interstices with a single row of regular relatively large elongate cells; pubescence scarce, short and decumbent. Femoris and tibiae straight, relatively broad; tarsomeres 2-4 widened, tarsomere 1 with plantar pad on ca. apical fourth (Fig. 44).

Aedeagus robust, with bullet-shaped in frontal aspect and provided with apical flattened hook and inwardly curved paired inner sac spikes in lateral aspect median lobe; phallobase relatively long, ca. 0.35 length of median lobe, and broad (Figs 49-50).

Female. Unknown.

Length: $7.0 \mathrm{~mm}$. Width (humerally): $1.7 \mathrm{~mm}$.

DIAGNOSIS. Xylobanus ziminae sp.n. is readily distinguishable from all Xylobanus species of the region by the long antennal flabellae, large median pronotal areole and dark bottom of the elytral cells, with gradual transition border between reddish brown and black elytral parts, as well as by the bullet-shaped in frontal aspect and provided with apical flattened hook in lateral aspect median lobe of the aedeagus (Figs 44, 49-50)

ETYMOLOGY. The new species is named after Ms. Svetlana Kurbatova (Zimina) (Moscow), the collector of the type specimen.

Calochromini Lacordaire, 1857

Type genus: Calochromus Guerin-Meneville, 1833.

Calochromus Guerin-Meneville, 1833

Type species: Calochromus glaucopterus Guerin-Meneville, 1833.

\section{Calochromus pardus Kazantsev, sp.n.} Fig. 41.

MATERIAL. Holotype,, , [E] Malaysia: Sabah prov., Banjaran Crocker Mts, Gunung Alab peak, 1650-1800 m, 30.IV-27.V.1996, M. Strba \& R. Hergovits leg. (ICM).
DESCRIPTION. Female. Black; elytral costae and transverse ribs, except narrowly at humeri and in distal fifth, reddish brown; bottom of elytral cells black.

Vertex shining, finely and scarcely punctate, slightly convex, antennal prominence inconspicuous, with short shallow median impression. Eyes small, interocular distance ca. 2.1 times greater than eye diameter. Clypeus almost straight anteriorly, fused with cranium without suture; labrum small, semicircular anteriorly. Maxillary palps slender, ultimate palpomere bulbous, oval, oblique and glabrous distally. Antennal sockets separated by broad lamina. Antennae flattened, serrate, attaining to elytral middle, broad in middle antennomeres, tapering distally; antennomere 3 ca. 2.2 times longer than antennomere 2 and ca. 1.4 times shorter than antennomere 4; antennomeres 2-11 with short decumbent pubescence (Fig. 41).

Pronotum transverse, ca. 1.3 times as wide as long, broadest near middle, slightly narrowing anteriorly, convex at sides and at anterior and posterior margins, with noticeable blunt posterior and rounded blunt anterior angles; margins narrowly thickened throughout; median impression complete and relatively well defined, lateral folds moderately large. Scutellum subquadrate, nearly straight at apex (Fig. 41).

Elytra long, ca. 3.6 times longer than wide at humeri, conspicuously widened distally, widest in distal two thirds, with four equally developed primary costae, almost obliterate in distal fifth; all interstices, except interstice 5, with one row of large elongate oval cells; pubescence dense, short and decumbent. Femoris and tibiae straight, relatively broad; tarsomeres widened, tarsomere 1 with plantar pad on almost its entire length (Fig. 41).

Male. Unknown.

Length: $10.4 \mathrm{~mm}$. Width (humerally): $2.5 \mathrm{~mm}$.

DIAGNOSIS. Calochromus pardus sp.n. is readily distinguishable from other Calochrmus species by the elytral structure and coloration pattern (Fig. 41).

ETYMOLOGY. The name of the new species is derived from the Latin for "leopard", alluding to its elytral coloration.

ACKNOWLEDGEMENTS. I wish to thank Sabah Parks for granting research permit. It is also my pleasant duty to express gratitude to Dr. A. Kompantsev, Dr. S. Kurbatov, Ms. Sv. Zimina and Dr. N. Vikhrev (Moscow) for handing over lycids collected during their trips to Sabah.

\section{References}

Bourgeois J. 1883. Lycides nouveaux ou peu connus du Musée civique de Gênes // Annali del Museo Civico di Storia Naturale di Genova. Vol.18. P.621-648.

Bourgeois J. 1892. Descriptions de trois espéces nouvelles de Lycides de Bornéo // Notes from the Leyden Museum. Vol.14. P.39-42.

Bourgeois J. 1906. Les Lycides du Sarawak Muséum (Bornéo) // Annales de la Société entomologique de France. Vol.75. P.184194.

Kazantsev S.V. 1997. New and little known Lycidae (Coleoptera) from Southeast Asia // Raffles Bulletin of Zoology. Vol.45. No.2. P.173-187.

Kazantsev S.V. 1998. Two new oriental genera of the tribe Lyropaeini (Coleoptera: Lycidae) // Elytron. Vol.12. P.15-22.

Kazantsev S.V. 2003. A generic review of Duliticolinae, new subfamily (Coleoptera, Lycidae) // Elytron. Vol.16 (2002). P.5-21.

Kazantsev S.V. 2004. Contribution to the knowledge of Macrolycini with description of Calcaeron, new genus (Coleoptera, Lycidae) // Zootaxa. Vol.493. P.1-32.

Kazantsev S.V. 2009. New taxa of Platerodrilini (Coleoptera: Lycidae) // Russian Entomological Journal. Vol.18. No.1. P.55-62. 
Kazantsev S.V. 2014. New and little known species of Plateros Bourgeois, 1879 (Lycidae, Coleoptera) from Sundaland // Russian Entomological Journal. Vol.23. No.3. P.179-190.

Kleine R. 1926a. XX. - Some Lycid Beetles from Mt. Poi and Mt. Penrissen in Sarawak // Sarawak Museum Journal. Vol.10. P.359-361.

Kleine R. 1926b. XXI. - Protaphes, a new genus from Sarawak // Sarawak Museum Journal. Vol.10. P.363-365.

Kleine R. 1927a. Bestimmungstabelle der Gattung Xylobanus C.O.Waterhouse // Tijdschrift voor Entomologie. Bd.70. S.4372.

Kleine R. 1927b. Neue Lyciden von den Sunda-Inseln // Treubia. Vol.9. No.4. P.293-31, 3Tbn

Kleine R. 1928. Dr. Mjoebergs Lycidenausbeute aus dem oestlischen Borneo // Stettiner Entomologische Zeitung. Bd.89. S.313-331.

Kleine R. 1932. Die Lycidenfauna der Gebirge Borneos (Zugleich ein Bericht über die Ausbeute die Herr H. M. Pendlebury aus dem Kina-Balu-Gebirge mitgebracht hat.) // Journal of the Federated Malay States Museums. Vol.17. P.146-166.

Kleine R. 1933a. Neue Lyciden und Bemerkungen zum Cat. Col. Junk-Schenkling Lycidae // Stettiner Entomologische Zeitung. Bd.94. Hf.1. S.1-20.
Kleine R. 1933b. Pars 123: Lycidae // Coleopterorum Catalogus auspiciis et auxilio W. Junk editus a Schenkling. Berlin: W. Junk. 145 p.

Malohlava V., Bocák L. 2009. A revision of Paratelius Kazantsev, 1992 (Coleoptera: Lycidae) // Zootaxa. Vol.2306. P.44-50.

Malohlava V., Bocák L. 2011. A revision of the neotenic genus Scarelus (Coleoptera: Lycidae) // Annales de la Société entomologique de France. N.S. Vol.47. No.1-2. P.176-192.

Pic M. 1912. Contribution à l'étude du genre "Scarelus" Wat. // Mélanges exotico-entomologiques. Vol.3. P. 4-5.

Pic M. 1936. Quelques Coléoptères nouveaux de la presqu'île Malaise (III) // Journal of the Federated Malay States Museum. Vol.18. No.1. P.54-59.

Waterhouse C.O. 1878. On the different forms occurring in the Coleopterous family Lycidae, with descriptions of new genera and species // Transactions of Entomological Society of London. Vol.1. P.95-118.

Waterhouse C.O. 1879. Illustrations of Typical Specimens in the Collection of the British Museum. Part 1 - Lycidae. London: Taylor and Francis. 93 p.

Zaragoza Caballero S. 1999. Cantharoidea (Coleoptera) de Mexico. III. El genero Plateros Bourgeois (Lycidae: Erotinae: Platerodini) // Acta Zool. Mex. (n.s.). Vol.78. P.1-71. 